\title{
SPECIALTY NATURAL RUBBER LATEX FOAM: FOAMABILITY STUDY AND FABRICATION PROCESS
}

\author{
ROSLIM RAMLI, ${ }^{1,2,3 *}$ AI BAO CHAI, ${ }^{2}$ JEE HOU HO, ${ }^{2}$ SHAMSUl KAMARUdDIN, ${ }^{1}$ FATIMAH RUBAIZAH \\ MOHD RASDI, ${ }^{1}$ DAVIDE S. A. DE FOCATIIS ${ }^{3}$ \\ ${ }^{1}$ Technology and Engineering Division, Malaysian Rubber Board, SElangor, Malaysia \\ ${ }^{2}$ Faculty of Science and EngineERING, University of NotTingham Malaysia, Selangor, Malaysia

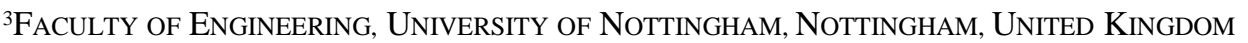

RUBBER CHEMISTRY AND TECHNOLOGY

\begin{abstract}
Specialty natural rubber (SpNR) latex namely deproteinized natural rubber (DPNR) latex and epoxidized natural rubber (ENR) latex have been produced to meet specific product's requirements. However, SpNR is normally used in the form of block rubber to manufacture dry rubber products such as tires and automotive parts. This study aims to diversify the applications of SpNR latex into latex foam products. This study found that, foamability of SpNR latex is lower compared to normal latex (LATZ), but shows longer stability time after foamed. This study also found that, foam collapse and foam coagulate are two main challenges in the fabrication process of SpNR latex foam. Despite these challenges, SpNR latex foam can be fabricated at different density levels. During the foaming process, additional foaming agent is required to fabricate a SpNR latex foam, which is different from fabricating a normal NR latex foam, especially at low latex foam density. Consequently, a higher level of sodium silicofluoride, used as the gelling agent, is required to set the cell structure of the foam. This study also found that, foam density influenced the gelling time and volume shrinkage of the SpNR latex foam. In this work, an ideal compounding, foaming and gelling formulation to fabricate SpNR latex foam via Dunlop batch foaming process have been developed. Morphological study showed that all latex foams are open-cell structure, with lower density foam exhibits higher porosity and mean pore size. Comparison on hysteresis behavior between DPNR and ENR latex foam indicated that, ENR latex foam exhibits higher hysteresis loss ratio compared to DPNR latex foam.
\end{abstract}

\section{INTRODUCTION}

At present, microcellular polymers which are also known as polymer foams have received considerable attention among academia and industrial players due to their lower density and lighter weight, lower thermal conductivity, and higher load bearing strength per weight compared to normal non-cellular polymeric materials. ${ }^{1-4}$ These properties are beneficial in numerous applications such as building \& construction, packaging, furniture $\&$ bedding, footwear, sports \& recreational, aeronautic and automotive industries. ${ }^{5,6}$ Furthermore, the porous structure of polymer foam make them an excellent substitute for various functional materials that are used as barriers such as thermal and sound barriers, impact absorbers, and vibration dampers. ${ }^{7}$ The versatility and diverse applications of polymer foams have contributed to gradual world economic growth and was worth more than USD 100 billion in 2015, and is expected to increase up to USD 150 billion by $2025 .^{8}$

Nevertheless, most of the polymer foam products available in the market are made from synthetic polymers (petrochemicals) which contribute to environmental and health issues, as well as challenging waste management and disposal problems. ${ }^{9,10}$ Therefore, many countries have implemented new legislation to restrict utilization of synthetic polymers in the products manufacturing process, and at the same time to promote utilization of "green materials". ${ }^{11-13}$ Consequently, many related research studies have been carried out by numerous universities, 
government research institutes as well as private companies to strive a balance between economic growth and well-being of the environment and society. A possible solution is to substitute synthetic polymers with natural polymers. However, substituting synthetic polymers with natural polymers is a great challenge. This is because most of the natural polymers are unable to comply with the foam product specifications and performances. ${ }^{4,14,15}$

Natural rubber (NR) latex is a high molecular weight hydrocarbon polymer of isoprene $\left(\mathrm{C}_{5} \mathrm{H}_{8}\right)$, whereas one double bond unit exists for each $\mathrm{C}_{5} \mathrm{H}_{8}$ group. ${ }^{16} \mathrm{NR}$ latex occurs in the free-flowing milky cytoplasmic exudates of the commercial rubber trees known as Hevea brasiliensis.NR latex has become the material of choice for many thin-film products such as gloves, condoms, catheters, balloons etc. due to its elasticity, durability and being a natural and biodegradable material. ${ }^{17,18}$ Apart from thin films, NR latex also has been used to produce foam material known as latex foam. However, the application of latex foam is limited to bedding products such as mattresses and pillows. ${ }^{16}$ The reason behind this is unclear but it could be due to the lack of studies in this area.

Currently, there are two main types of NR latex that have been used to manufacture latex foam products, namely high ammonia NR (HA) latex and low ammonia NR (LATZ) latex. However, there are also other forms of NR latex known as specialty NR (SpNR) latex such as epoxidized NR (ENR) latex and deproteinized NR (DPNR) latex. SpNR latex is a modified NR latex produced to meet specific product requirements such as good wet-grip, high damping, low creep and low-stress relaxation as well as low extractable protein content. ${ }^{19-24}$ Nevertheless, product applications of SpNR are relatively limited and normally used in the form of block rubber to manufacture dry rubber products such as tires and automotive parts. 19,25,26 To date, less information is reported concerning the utilization of SpNR in latex-based products. Application of SpNR latex in latex foam products is almost impossible due to their low total solid content (TSC) at 30\%. This is because low TSC of latex leads to high volume shrinkage and variable physical properties, which is a great challenge in latex foam products manufacturing process. ${ }^{27}$

To address this issue, Malaysian Rubber Board (MRB) has developed a new generation of SpNR latex, whereas the TSC of SpNR latex has increased to 60\% TSC through the ultrafiltration process using membrane separation technology. ${ }^{28-30}$ The availability of SpNR latex with higher TSC has provided an opportunity to diversify the application of SpNR latex into latex foam products. It is well-known that, the porous open-cell structure of foam materials is useful to absorb noise and minimize vibration transmission from one area to another. ${ }^{31-35}$ Therefore, it is a great opportunity to utilize the SpNR latex foam for sound and vibration control applications such as acoustics foam material and seat cushions in transportation industry. The advantage of using ENR latex is due to its high-damping property originated from the epoxy group in the rubber chains. ${ }^{19-21,36}$ On the other hand, the advantage of using DPNR latex is due to its low protein content which leads to hypoallergenic material and less smell of rubber. ${ }^{22-24,37}$ However, there are a few challenges to develop latex foam from SpNR latex. First, physicochemical properties of SpNR latex are expected to be differed from normal NR latex due to chemical reactions during SpNR latex modification process. Second, there is a gap in knowledge on foamability and subsequence stability of SpNR latex. Therefore, the objectives of this study are to investigate foamability and stability of SpNR latex, and to develop a compounding, foaming and gelling formulation to fabricate a SpNR latex foam. Additionally, the physical properties of the fabricated SpNR latex foam material will be determined. Knowledge gained from this study is important not only to provide a method and formulation to fabricate SpNR latex foam but their potential applications can be identified. 


\section{SPECIALTY NATURAL RUBBER LATEX FOAM: FOAMABILITY STUDY AND FABRICATION PROCESS}

\section{EXPERIMENTAL}

\section{MATERIAL PREPARATION AND COMPOSITION}

In this work, both ENR and DPNR latex of 60\% TSC were prepared from freshly tapped NR latex collected from MRB Plantation, Johor, Malaysia. All chemicals used were purchased from Sigma-Aldrich (M) Sdn. Bhd., Selangor, Malaysia. In brief, ENR latex was prepared through in-situ chemical reactions of hydrogen peroxide and formic acid which substitutes the double bond structure to generate an epoxy group onto the rubber molecules. ENR latex was prepared in accordance to MRB standard process and formulation patented in PI2012004868 ${ }^{38}$ and PI2017700457 ${ }^{39}$ respectively. The production of ENR latex involves heating of freshly tapped NR latex having TSC of $30 \%$, with $2.0 \%$ non-ionic surfactant, $0.75 \mathrm{~mol}$ formic acid and $1.00 \mathrm{~mol}$ hydrogen peroxide in a jacketed reactor. The NR latex mixture was heated at temperature of $45{ }^{\circ} \mathrm{C}$ for an hour, $50{ }^{\circ} \mathrm{C}$ for another 3 hours and finally $60{ }^{\circ} \mathrm{C}$ for a further 21 hours. This allows the epoxidation reactions to take place. Once the targeted epoxidation was achieved, the ENR latex was cooled down to the room temperature, and neutralized using ammonia to $\mathrm{pH} 7$ to terminate the epoxidation reaction. Then, the ENR latex was subjected to a concentration process using ultrafiltration membrane separation system, to obtain ENR latex concentrate having a TSC content of approximately 60\%. After that, the ENR latex was preserved using ammonia laurate to $\mathrm{pH} 10$ to ensure stability of the material. On the other hand, DPNR latex was prepared in accordance to MRB standard process and formulation patented in PI2020004246. ${ }^{40}$ In brief, the deproteinization was carried out via heat enzymatic hydrolysis reactions. The production of DPNR latex involves heating freshly tapped NR latex having TSC of $30 \%$ with $2.0 \%$ non-ionic surfactant, $0.15 \%$ alcalase and $0.15 \%$ hydroxylamine neutral sulphate in a jacketed reactor. The NR latex mixture was heated to a temperature of $60^{\circ} \mathrm{C}$ for 6 hours to allow the heat enzymatic hydrolysis reactions to take place. After the completion of the heat enzymatic hydrolysis reactions, the reacted DPNR latex mixture was cooled down to room temperature. Then, the DPNR latex was pumped into the ultrafiltration membrane separation system to obtain DPNR latex concentrate having a TSC content of approximately $60 \%$, similar to the ENR latex process. Finally, the DPNR latex was preserved with ammonium laurate and ammonia at levels of $0.1 \%$ and $0.4 \%$ respectively. For comparative study, a commercial grade low ammonia NR latex (LATZ) purchased from Getahindus (M) Sdn. Bhd, Johor, Malaysia was used as a control. The actual composition of LATZ is unknown but it normally contains $0.2 \%$ ammonia, $0.013 \%$ tetramethyl thiuram disulphide (TMTD), $0.013 \%$ zinc oxide and $0.05 \%$ lauric acid. LATZ was chosen as a control because LATZ is a commonly used NR latex for producing latex foam products such as mattresses and pillows in beddings industry ${ }^{41,42}$. Likewise, LATZ is the material of choice in bedding industry due to its reduced ammonia content which offers a safer manufacturing environment.

\section{LATEX COMPOUNDING PROCESS}

Table I shows the compounding formulation used in this work. The compounding formulation used in this study is a commonly-used sulphur-vulcanized system. ${ }^{42}$ All chemicals used for the compounding process were purchased from Alpha Nanotech Sdn. Bhd., Selangor, Malaysia. In this work, all vulcanizing agents were mixed first and allowed to activate at room temperature for 30 minutes. Sulphur and zinc diethyl dithiocarbamate (ZDEC) play the main role in the crosslinking of the rubber molecular chains to produce vulcanized latex foam material, whilst the presence of zinc 2-mercaptobenzothiazole (ZMBT) as a secondary accelerator helps to increase the compression modulus and reduce the compression set of the latex foam. However, small changes were made in this work, whereas zinc oxide $(\mathrm{ZnO})$ and 


\section{RUBBER CHEMISTRY AND TECHNOLOGY}

zinc dibutyl dithiocarbamate (ZDBC) were used as part of the vulcanizing ingredients. Both chemicals were used to improve the pre-vulcanization process of the latex compound which helps to accelerate the vulcanization process and to reduce the volume shrinkage of the end products. Upon compounding process, potassium oleate (P.O.) was added first into the latex, followed by a premix vulcanizing agent while the latex was being stirred at $100 \mathrm{rpm}$. The stirring process lasted for two hours. Then, the speed of the stirrer was reduced to $45 \mathrm{rpm}$ and the latex was allowed for maturation at room temperature for 16 hours. ${ }^{43}$

Table I

Compounding Formulation Used in This Study

\begin{tabular}{lcc}
\hline Ingredient & TSC $(\%)$ & Dry weight (phr) \\
\hline Latex $^{\mathrm{a}}$ & 60 & 100 \\
Potassium oleate & 20 & 1.50 \\
Sulphur dispersion & 60 & 2.50 \\
Zinc oxide (ZnO) dispersion & 60 & 0.15 \\
Zinc diethyl dithiocarbamate (ZDEC) dispersion & 50 & 0.75 \\
Zinc dibutyl dithiocarbamate (ZDBC) dispersion & 50 & 0.25 \\
Zinc 2-mercaptobenzothiazole (ZMBT) dispersion & 50 & 1.0 \\
Antioxidant dispersion (Wing stay-L) & 50 & 1.0 \\
\hline
\end{tabular}

${ }^{\mathrm{a}}$ LATZ, ENR and DPNR latex

$\mathrm{phr}=$ parts per hundred rubber

\section{FOAMABILITY AND STABILITY STUDY}

This study was conducted to quantify the foamability and subsequence stability of SpNR latex foam over time. Foamability is the ability of the latex to change from colloid/liquid phase into latex foam phase when it is subjected to a constant rate of mechanical rotating motion. On the other hand, stability refers to the durability of the latex foam to retain the foam-cell structure before drainage (a tendency of the latex foam to change back into liquid phase). In this work, a FoamScan ${ }^{\circledR}$ analyzer from Teclis, France was used.
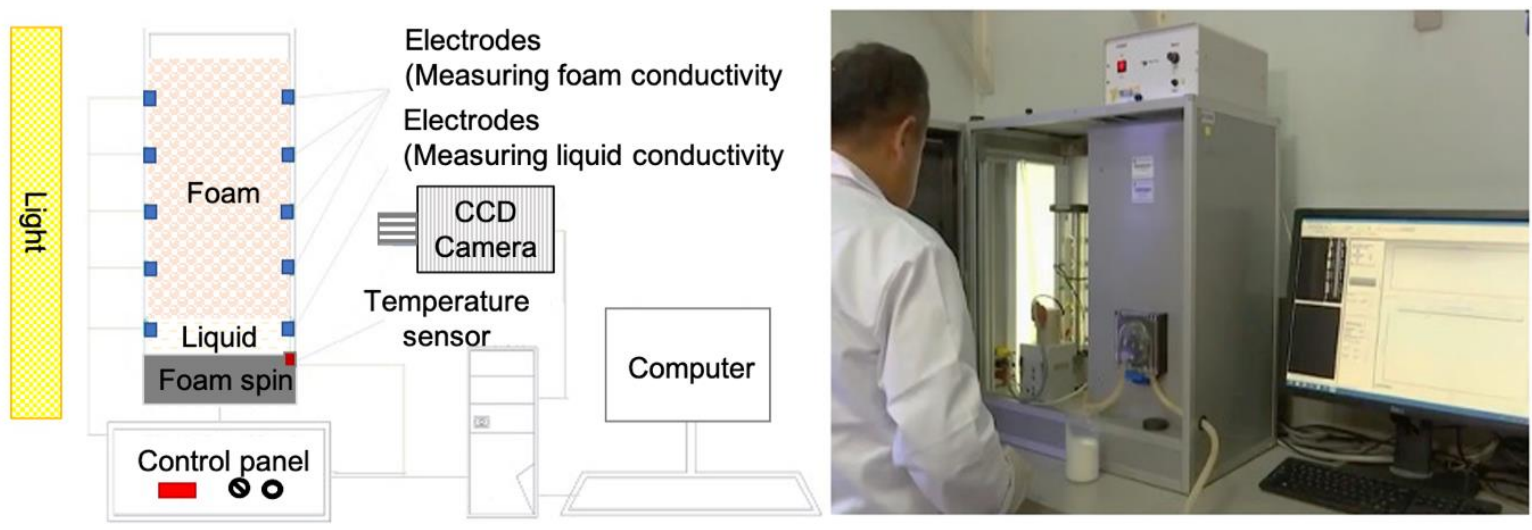

FIG. I. FoamScan ${ }^{\circledR}$ analyzer configuration

Figure I show the instrument configuration. To the best of our knowledge, study on the foamability and stability of NR latex using FoamScan ${ }^{\circledR}$ analyzer has not yet established, thus experimental parameters were set in this particular study. In this work, $60 \mathrm{~mL}$ of latex was injected into a glass tube with an inner diameter of $35 \mathrm{~mm}$. Latex foam was generated through whipping process using a high-speed rotary spin located at the bottom of the tube. A constant rate of $1000 \mathrm{rpm}$ was set to foam the latex, under a controlled temperature of $25^{\circ} \mathrm{C}$. The latex foaming process stopped automatically when the foaming time reached 600 seconds. Then, the 


\section{SPECIALTY NATURAL RUBBER LATEX FOAM: FOAMABILITY STUDY AND FABRICATION PROCESS}

latex foam stability was observed for another 600 seconds. An integrated camera was used to capture images of the foams microscopically throughout the experiment. Foamability and stability of the latex was quantified in terms of volume expansion and foam decays respectively. The foaming process latex foam using FoamScan ${ }^{\circledR}$ analyser slightly different compared to the actual foaming process using Kenwood mixer especially the design of the rotary blade and the speed of the whipping process. Nevertheless, FoamScan ${ }^{\circledR}$ analyzer is the only instrument available that allows researchers to visualize the microscopic transition of latex from liquid phase into foam phase, thus allow further study on foamability and subsequence stability of the SpNR latex foam.

\section{FOAMING, GELLING AND FABRICATION PROCESS}

The fabrication of latex foam in this work is similar to the conventional Dunlop batch foaming process ${ }^{42,43}$ which involves compounding, foaming, gelling, molding, vulcanizing, washing and drying process (Figure II). Table II shows gelling formulation used in this study. In this work, the maturated latex compound was weighted accordingly and poured into a Kenwood mixer. Mechanical agitation was applied, whereas the Kenwood mixer stirrer rotated in a planetary motion at high speed. This whipping action resulted in air entrapped inside the latex compound. In this study, three wet density levels of latex foam, namely high-density $(0.16$ $\left.\mathrm{g} / \mathrm{cm}^{3}\right)(\mathrm{HD})$, medium-density $\left(0.12 \mathrm{~g} / \mathrm{cm}^{3}\right)(\mathrm{MD})$ and low-density $\left(0.09 \mathrm{~g} / \mathrm{cm}^{3}\right)$ (LD) were prepared. This was achieved by controlling the weight of the latex and the volume expansion of the latex foam during the foaming process. In this work, the targeted volume of the latex foam is $5000 \mathrm{~mL}$, therefore the latex foam was whipped until it reached a level of volume marked at the bowl. This may require a duration of five to six minutes. Additionally, during the foaming process, a latex foam sample was taken out from the bowl mixer and poured into a $50 \mathrm{~mL}$ beaker to determine the wet density of the latex foam.
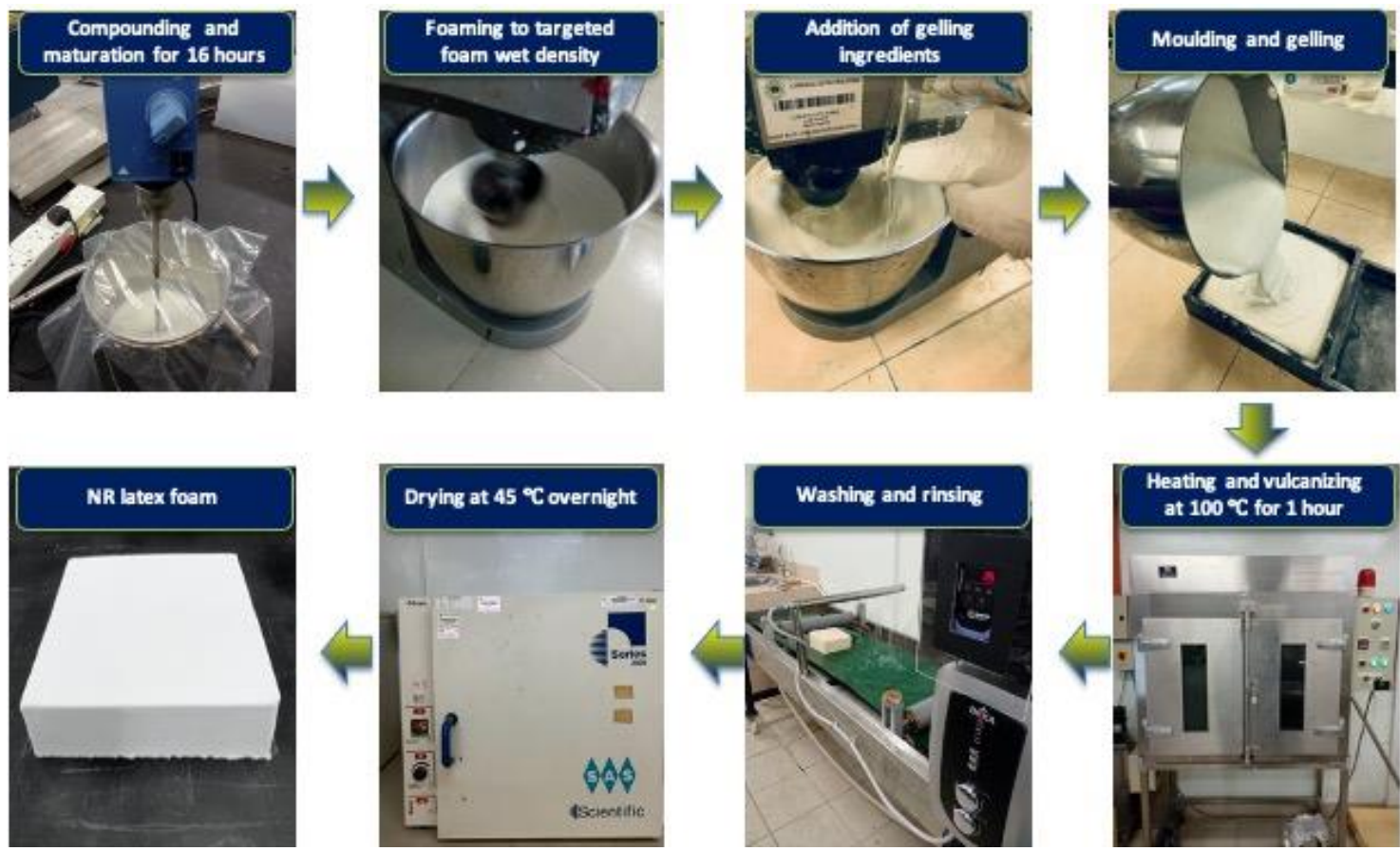

FIG. II. The different stages involved in the fabrication of NR latex foam using the Dunlop batch foaming process

The foaming behavior of each type of latex examined in this study were elucidated, and the actual dosage of gelling ingredient for each type of latex at the targeted three density levels was determined. In this work, the latex foam that had been whipped to the targeted density levels was refined by slowing down the rotation speed from $400 \mathrm{rpm}$ to $140 \mathrm{rpm}$ and allowed 
the foam to be continuously stirred for another two minutes to refine the foam-cell structure. During the refining stage, all large bubbles were eliminated, and thus resulted in more uniform foam cell size. Then, gelling ingredients listed in Table II were added. Zinc oxide ( $\mathrm{ZnO})$ dispersion was added first, followed by the addition of diphenyl guanidine (DPG) dispersion. DPG is a secondary delayed-gelling agent, also act as a secondary accelerator during the vulcanization process. ${ }^{42}$ After that, a gelling agent was added.

Table II

Gelling Formulation Used in This Study

\begin{tabular}{|c|c|c|c|c|c|}
\hline \multirow[t]{2}{*}{ Ingredient } & \multirow[t]{2}{*}{$\operatorname{TSC}(\%)$} & \multirow[t]{2}{*}{$\begin{array}{c}\text { Dry weight } \\
\text { (phr) }\end{array}$} & \multicolumn{3}{|c|}{ Wet weight $(\mathrm{g})$} \\
\hline & & & HD & MD & LD \\
\hline Latex $^{a}$ & 60 & 100 & 800 & 600 & 450 \\
\hline Diphenyl guanidine dispersion & 40 & 0.3 & 3.6 & 2.7 & 2.0 \\
\hline Zinc oxide dispersion & 60 & 5.0 & 40 & 30 & 22.5 \\
\hline Sodium silicofluoride dispersion & 50 & $0.4-1.3 *$ & & & \\
\hline
\end{tabular}

Sodium silicofluoride (SSF) dispersion in combination with $\mathrm{ZnO}$ dispersion is the primary gelling agent used in NR latex foam industry. Although SSF is usually prepared at 50\% TSC, in this study, it is proposed that the SSF may be with advantage to be diluted to $20 \%$ TSC prior to addition to the latex foam to avoid sudden gelation of the latex foam. According to Blackley, ${ }^{42}$ when $\mathrm{pH}$ value drops, the zinc complexes will react with soap (potassium oleate) to form zinc soap gradually, and therefore removes the protective layer of foam-cell. At this point, SSF is added and gradually hydrolyzed so that the latex foam can be gradually gelled. The actual dosage of SSF may vary depending on the type of latex, alkalinity, amount of soap used, the density levels and the speed of gelation required. Therefore, the dosage of SSF required for each type of latex and density levels were determined experimentally. In this work, SSF was diluted first to $20 \%$ TSC prior to addition into latex foam. Consequently, a glass electrode of a $\mathrm{pH}$ meter model HANNA Instruments 2210 was placed into the latex foam. A $\mathrm{pH}$ meter accurately measured the $\mathrm{pH}$ change in the latex during gelation process. The methodology is based on the direct determination of hydrogen ion concentration in the solution. Normally, NR latex foam is gel at $\mathrm{pH} 8.5 .^{27,42}$ In this study, the effect of SSF levels on gelling time and $\mathrm{pH}$ values were investigated.

After a suitable level of SSF was added, the latex foam was poured into a square shape mold of $200 \times 200 \times 40 \mathrm{~mm}$ (length $\mathrm{x}$ width $\mathrm{x}$ height). In this work, the latex foam was allowed to gel and rest at room temperature for five minutes before being transferred into a hot air oven at a temperature of $100{ }^{\circ} \mathrm{C}$ and vulcanized for 60 minutes. Vulcanization is a chemical reaction that gives the latex foam its final fixed and elastic shape. After vulcanization, the mold is opened, and the vulcanized latex foam was peeled out from the mold and then subjected to a washing process to remove excessive soap, extractable proteins and residual chemicals. The washing operation is not critical, but this process is important to ensure that elasticity is retained and to counter ageing due to chemical residues. A typical process is by soaking the latex foam in warm water $\left(45^{\circ} \mathrm{C}\right)$, and then squeezes out the water through squeeze rollers. Then, the latex foam was subjected to a drying process. All samples were kept dry at room temperature before being subjected to testing.

\section{DETERMINATION OF WET FOAM DENSITY}

During the foaming process, the latex foam sample was taken out from the bowl mixer and poured into a $50 \mathrm{~mL}$ beaker to determine the wet density of the latex foam, to ensure each 


\section{SPECIALTY NATURAL RUBBER LATEX FOAM: FOAMABILITY STUDY AND FABRICATION PROCESS}

batch of latex achieved the targeted latex foam wet density. The wet density was calculated in accordance with Eq. 1.

$$
\text { Wet density }=\frac{\text { Mass of the sample }(\mathrm{g})}{\text { Volume of the beaker }\left(\mathrm{cm}^{3}\right)}
$$

\section{DETERMINATION DRY DENSITY}

During the foaming process, approximately $250 \mathrm{~mL}$ of latex foam was poured into a 250 $\mathrm{mL}$ square container. Then, the latex foam sample was subjected to a similar fabrication process. The dry density of the latex foam was determined in accordance with Eq. 2.

$$
=\frac{\text { Mass of the specimen }(\mathrm{g})}{\text { Volume of the specimen }\left(\mathrm{cm}^{3}\right)}
$$

\section{DETERMINATION OF VOLUME SHRINKAGE}

Volume shrinkage is an important property in latex foam technology as it determines the size of the finished latex foam products. Volume shrinkage was calculated as a percentage and measured from the difference in dimension between the mold and the fabricated foam(Eq. 3). ${ }^{27}$

$$
\text { Volume shrinkage }=\frac{\text { Mould size }\left(\mathrm{cm}^{3}\right)-\text { Latex foam size }\left(\mathrm{cm}^{3}\right)}{\text { Mould size }\left(\mathrm{cm}^{3}\right)} \times 100 \%
$$

\section{MORPHOLOGICAL STRUCTURE STUDY}

Scanning electron microscopy (SEM) was used to visualize the morphological structure of the foam samples. A test portion of $5 \mathrm{~mm} \times 5 \mathrm{~mm} \times 5 \mathrm{~mm}(\mathrm{~L} \times \mathrm{W} \times \mathrm{H})$ from the samples was cut and attached to a specimen stub using a carbon double-sided tape. The specimen was coated with an ultra-thin layer of platinum under a high vacuum evaporate process before visualizing under SEM operated at $15 \mathrm{kV}$. The SEM images were captured at $40 \mathrm{x}$ magnification. Images obtained from SEM were then analyzed using ImageJ software to quantify the porosity and pore size of the latex foams.

\section{STRESS-STRAIN COMPRESSION TEST}

A compression test is normally used to determine the compressive strength and energy absorption of a material ${ }^{44}$. In this work, DPNR latex foam prepared at dimension of $200 \mathrm{~mm} \mathrm{x}$ $200 \mathrm{~mm} \times 40 \mathrm{~mm}$ (length $\mathrm{x}$ width $\mathrm{x}$ height) was used. On the other hand, for PUF and CMF, foam samples cut at dimension of $200 \mathrm{~mm}$ x $200 \mathrm{~mm}$ x $50 \mathrm{~mm}$ (length x width x height) were used. The test was carried out using a $25 \mathrm{kN}$ servo-hydraulic MTS Multi-Axis testing machine. The test was carried out at room temperature $\left(\sim 25^{\circ} \mathrm{C}\right)$. The loading and unloading process was set to run for 5 cycles at a rate of $0.2 \mathrm{~Hz}$. Each sample was compressed up to $50 \%$ from its original height using a square platen. An assumption was made that during the loading and unloading process of the tests; there was no separation between the platen and the foam samples. The load (compression stress) and displacement behavior for each specimen is digitally recorded throughout the test.

\section{RESULTS AND DISCUSSION}

\section{EFFECT OF COMPOUNDING ON VISCOSITY AND PH VALUE OF LATEX}

Table III shows the effect of compounding on viscosity and $\mathrm{pH}$ value of the latexes. It is clear that $\mathrm{pH}$ value of all latexes was decreased, whilst the viscosity was increased. The decreased $\mathrm{pH}$ value could be due to the evaporation of ammonia from the latex during overnight 


\section{RUBBER CHEMISTRY AND TECHNOLOGY}

maturation process. On the other hand, the increased viscosity of the latex could be due to the chemical reactions of the vulcanizing ingredients. The viscosity of prevulcanized NR latex could be correlated to the colloidal stability of the material, in which depends on many factors such as prevulcanization temperature and time, the amount and type of stabilizers and the dosage of vulcanizing ingredients, as well as the TSC and particle size of the latex itself. Previous study ${ }^{45}$ indicated that, prevulcanization process has little effect on the viscosity of latex compound. Contradictorily, another study ${ }^{46}$ stated that the viscosity of NR latex increases due to the thickening effect resulted from the chemical reaction between soaps (in this case potassium oleate) and $\mathrm{ZnO}$ in the presence of ammonia in the latex system. This was further supported by Mathew and Varghese ${ }^{47}$ whereas, the soluble soaps converted into insoluble material due to reaction with $\mathrm{ZnO}$, thus increases the viscosity. Further to that, the presence of ZMBT as a secondary accelerator also can cause latex thickening (increase in viscosity) because ZMBT is slightly acidic and thus neutralizes alkali in the latex system. ${ }^{48}$

Table III

Effect of Compounding on Viscosity and $\mathrm{pH}$ Value of Latex Examined in This Study

\begin{tabular}{lccc}
\hline Stage of latex & $\begin{array}{c}\text { LATZ } \\
\text { pH/viscosity }\end{array}$ & $\begin{array}{c}\text { ENR } \\
\text { pH/viscosity }\end{array}$ & $\begin{array}{c}\text { DPNR } \\
\text { pHiscosity }\end{array}$ \\
\hline Latex concentrate & $9.70 / 70$ & $9.50 / 500$ & $9.61 / 115$ \\
Compounded latex & $9.46 / 135$ & $9.20 / 500$ & $9.35 / 175$ \\
\hline
\end{tabular}

\section{FOAMABILITY AND STABILITY STUDY}

Figure III shows that the foam volume of all latexes gradually increased with time due to the mechanical agitation process. In this experiment, the agitation process was automatically stopped after 600 seconds to elucidate the foamability of each latex. Apparently, all latexes could be foamed.
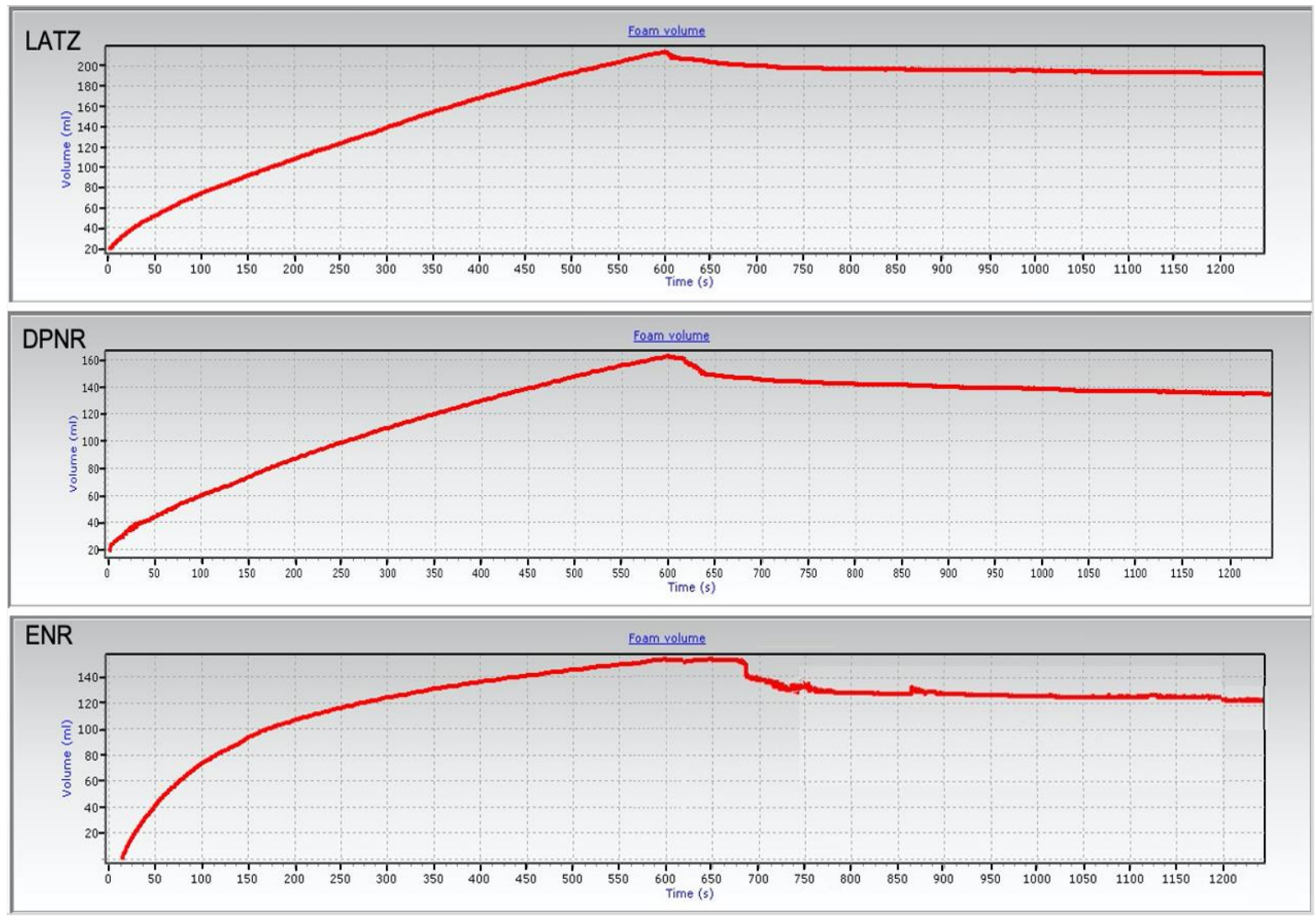

FIG. III. Foam volume versus time for LATZ, DPNR and ENR 


\section{SPECIALTY NATURAL RUBBER LATEX FOAM: FOAMABILITY STUDY AND FABRICATION PROCESS}

However, the foamability of each latex are differed. The study found that the LATZ, DPNR and ENR latex was foamed from $60 \mathrm{~mL}$ to $200 \mathrm{~mL}, 160 \mathrm{~mL}$ and $140 \mathrm{~mL}$ latex foam respectively. This indicates that LATZ latex exhibits the highest foamability followed by DPNR and ENR latex. According to Sun et al. ${ }^{49}$, the thicker the liquid, the slower the growth speed, in other words the slower the transition of the material from a liquid phase to a foam phase. Therefore, the foamability of each NR latex examined in this study might be influenced by the viscosity of the latex, whereas higher viscosity was less foamability of the latex. This correlates with viscosity results shown in Table III whereas, the viscosity of ENR latex is the highest, followed by DPNR and LATZ latex. Figure III also shows that ENR latex foam is more stable compared to DPNR and LATZ latex foam, whereas the foam is retained at a similar foam volume for 80 seconds before drainage. The stability of foam material is normally measured starting from decaying until half of its original volume has reached. Nevertheless, in this study, all latex foams are considered stable, because the drainage volume over time is less than $15 \%$.

Figure IV shows foaming images of the latex foams that were captured by an integrated camera. The grey area represents gas-phase encapsulated by latex film, whilst the darker area is the latex phase. The images show that at 300 seconds, all latex foams were still at the foaming stage. LATZ exhibits highest number of bigger foam-cell size, followed by DPNR and ENR latex foam. This correlates with Figure III, whereas LATZ shows the fastest foam's grow compared to DPNR and ENR latex foam.

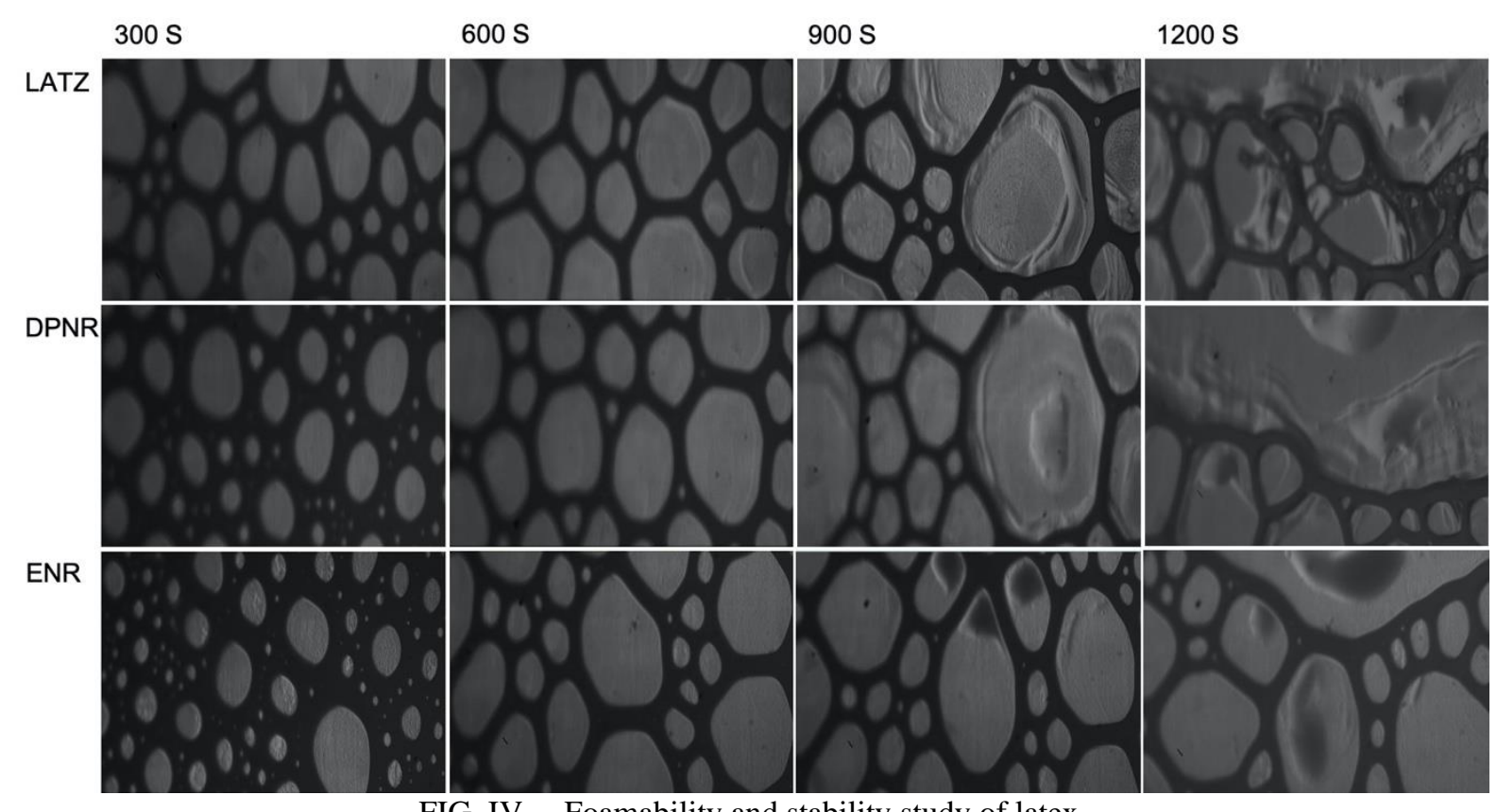

FIG. IV. - Foamability and stability study of latex

After the mechanical agitation automatically stopped at 600 seconds, the foam-cell size of each latex was visually compared. Assessing from the liquid film thickness (dark area) and foamcell size, LATZ and DPNR latex exhibit a moderately even liquid film thickness but unequal foam-cell size, thus the foam-cell structure of LATZ and DPNR latex is categorized as polynomial foams. ${ }^{49}$ On the other hand, for ENR latex foam, its liquid film thickness varies, and smaller foam-cell structure could be observed. This study assumed that addition of extra foaming agent in the latex system could increase the foamability of the latex thus a uniform liquid film thickness and foam-cell size of the latex foam could be obtained. 
Figure IV also demonstrates the foam-cell structure started to collapse after 900 seconds. This is due to the pressure difference between foam-cells and the gravitational force that causes the liquid film to drain out of the foam. This phenomenon has been explained by Sun et al. ${ }^{49}$ whereas, a pressure difference between smaller and bigger foam-cell has driven gas molecules trapped in the smaller foam-cell to diffuse into bigger foam-cell through liquid film. Gas molecules diffuse from smaller foam-cell into bigger foam-cell because the pressure in the smaller foam-cell is higher than the bigger foam-cell. Therefore the bigger foam-cells continue to grow bigger, eventually the liquid film ruptured and the foams collapse. Nevertheless, different type of latex might has different foam stability. It can be seen at Figure IV, after 900 seconds foam-cell structure of ENR latex is more stable compared to LATZ and DPNR latex foam. The reason behind this phenomenon is unclear but it is possibly due to the physiochemical properties (i.e., total solid content, dry rubber content, mechanical stability time, viscosity) of each latex. Previous $\operatorname{study}^{50}$ revealed that, the presence of non-ionic surfactant in the ENR latex system contributes to a high stability of the material. Additionally, the presence of non-ionic surfactant in the ENR latex system was observed to increase the viscosity of the latex. Previous study ${ }^{51}$ cited that, the viscosity of a liquid affects its foam stability whereas, higher viscosity exhibits higher fluid flow resistance, consequently reduces the foam drainage tendency. Thereby, the foam produced from higher viscosity is more stable. Table III indicated that, each latex has different viscosity, and ENR latex shows the highest viscosity followed by DPNR and LATZ latex. Therefore, ENR latex foam demonstrates a stable foam compared to LATZ and DPNR latex foam. This phenomenon can be observed in Figure III and microscopically visualized in Figure IV. Nevertheless, it should be noted that, the viscosity of each latex is influenced by the composition of the latex system, whereas both DPNR and ENR latex contain non-ionic surfactant to stabilize and preserve the latex from coagulation after the modification process. Further to that, as indicated in Figure III, the volume expansion of ENR latex foam is lower compared to LATZ latex foam and DPNR latex foam. However, at 1200 seconds all latex foams were observed to collapse.

\section{PRELIMINARY OBSERVATION AND STUDY ON FOAMING BEHAVIOR}

First, we recall that the first step of the Dunlop batch foaming process is compounding of the latex with vulcanizing agent together with a stabilizer which also acts as a foaming agent. Second, is to foaming the latex, whereas the latex changes from the liquid phase into the latex foam phase. This is followed by the addition of gelling ingredients to set the foam-cell structure. To develop foaming and gelling formulation for fabricating SpNR latex foam, it is crucial to determine relevant parameters controlling foaming and gelling behaviors of SpNR latex. This study observed that foam collapses and foam coagulate are two main challenges in producing SpNR latex foam (Figure V). It was noticed that there are few factors that lead to foam collapse such as volume expansion too high, levels of gelling agent not being suitable and latex foam too stable to be gel due to excessive stabilizer or surfactants. On the other hand, foam coagulate is mainly due to insufficient foam stabilizers and excessive gelling agent. This study also found that lower foam density requires additional P.O. to function as a foaming agent. However, the presence of a higher level of P.O. requires additional SSF to balance the gelling system. In a well-balanced latex foam foaming and gelling formulation, the latex foam required about five to seven minutes to set, and this must be regarded as the upper limit of time that is available for transferring the latex foam from the bowl to the mould. ${ }^{48}$ Normally, a secondary delayed-gelling agent such as DPG can be added to stabilize the foam-cell structure $^{16}$. Nevertheless, it should be noted that, many other factors might contribute to foam process failure such as viscosity, total solid content, chemicals stability of the latex as well as the type of chemical stabilizer used in the latex system. ${ }^{42}$ 


\section{SPECIALTY NATURAL RUBBER LATEX FOAM: FOAMABILITY STUDY AND FABRICATION PROCESS}

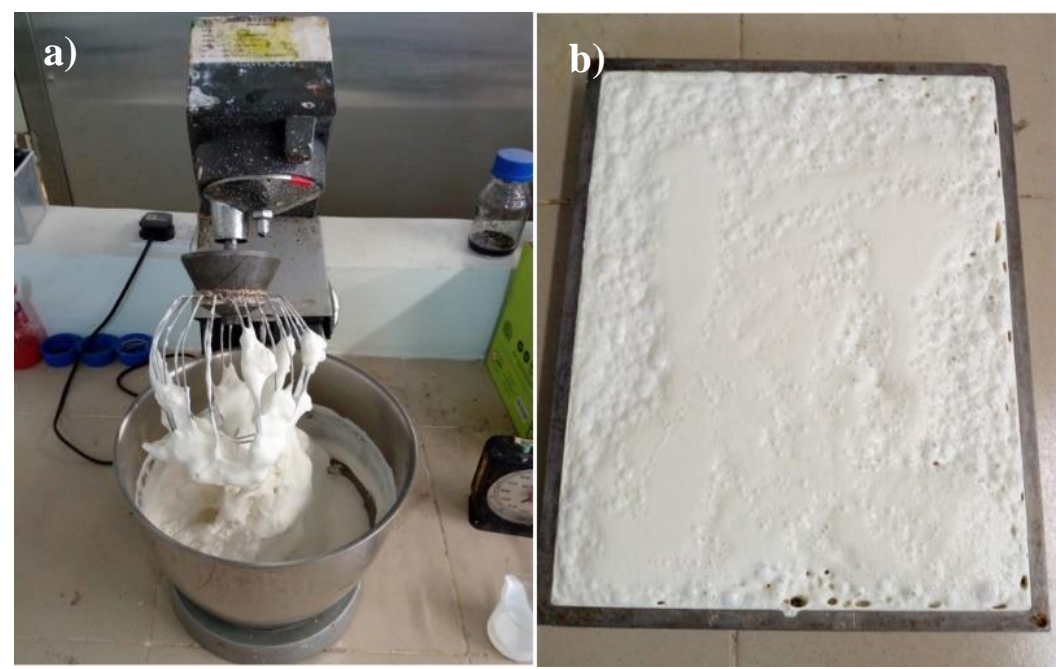

FIG. V. Failure during foaming process

a) Foam coagulate; b) Foam collapse

Besides foam collapse and foam coagulate, surface defects such as wrinkles, rat holes, coarse structure, flow marks and phase separation may occur if the gelling formulation is incorrect (Figure VI). Figure VI(a) shows surface wrinkles caused by an imbalance between zinc soap and acidic gelling agent, typically insufficient SSF. Figure VI(b) shows an example of phase separation whereas, the foam-cell size at the bottom part of the latex foam sample appeared to be smaller than the upper part.

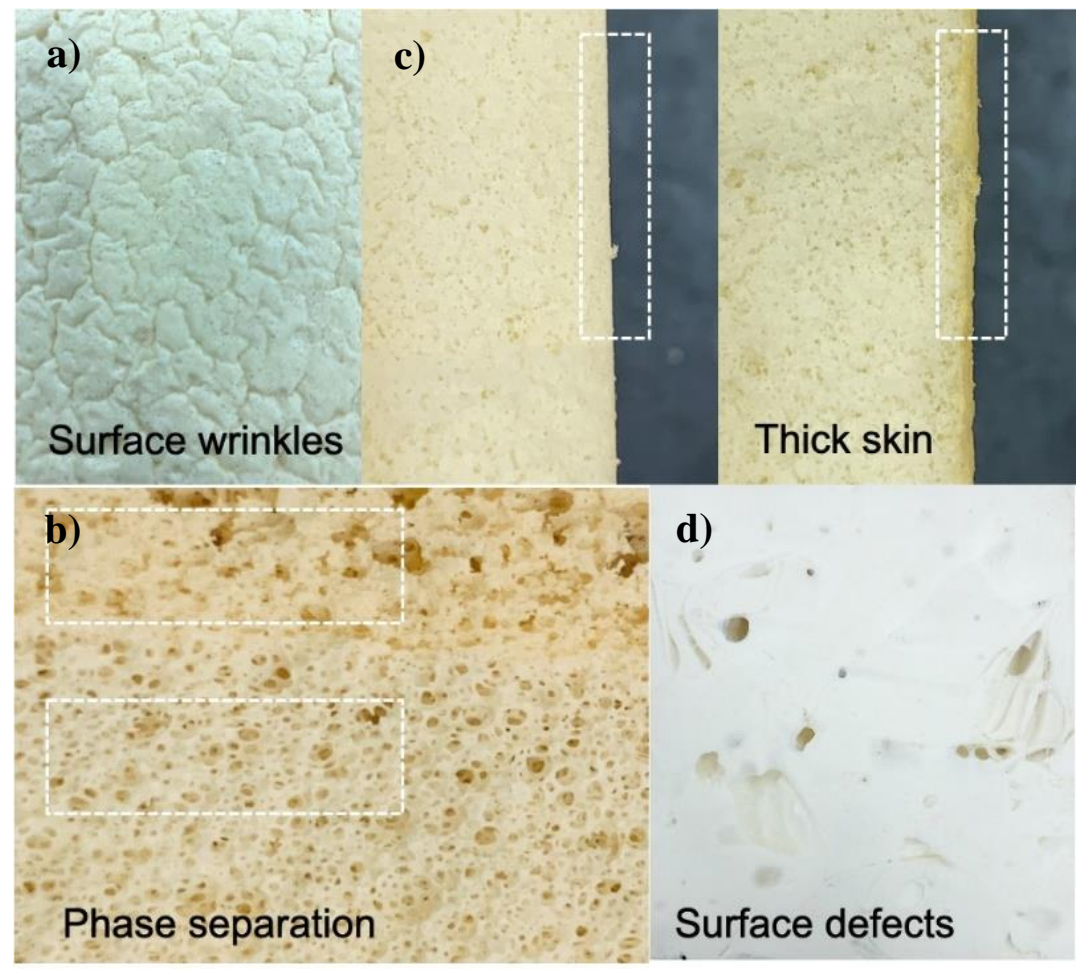

FIG. VI. Latex foam failure

a) Surface wrinkles; b) Thick skin; c) Phase separation; d) Surface defects

According to Blackley ${ }^{42}$, phase separation is a consequence of foam drainage caused by long gelling time. This is a situation whereas, the latex foam-cell structure slowly collapses due to the pressure difference between foam cells and gravitational forces. Figure VI(c) demonstrates a thick layer of skin that appeared at the bottom part of the latex foam. This is because the liquid foam that has been drained back into the liquid phase coalesce to become latex film. To 
address these issues, additional SSF should be added to set the latex foam-cell or locking latex foam at a consistent foam-cell structure. However, it is important to keep in mind that, too much SSF would cause the latex foam to coagulate in a very short period. Figure VI(d) demonstrates surface defects such as rat hole, coarse structure and flow marks. This is a consequence of incorrect gelling system whereas the gelling reaction occurred at low $\mathrm{pH}$ due to acidic gelling agent. ${ }^{52}$ Therefore, determination of actual dosage of SSF is important, especially in this study when different types of latex are used.

\section{FOAMING AND GELLING BEHAVIOR}

Table IV shows the wet density of the latex foam produced in this study. For LATZ latex, the latex was foamed to the targeted volume expansion within five minutes. The targeted wet density of HD, MD LD were achieved. For DPNR latex, it was observed that, for HD, the latex was foamed to the targeted volume expansion within five minutes. But, for MD and LD, the growth of the latex foam was found to be slightly slower, thus unable to reach the targeted volume expansion within five minutes. Although the foaming time has been extended to eight minutes, the latex foam was still unable to reach the targeted volume expansion. The latex foam was observed to reach only $3 / 4$ of the targeted volume expansion.

Table IV

Wet Density of The Latex Foam

\begin{tabular}{cccc}
\hline \multirow{2}{*}{ Parameters } & LATZ & ENR & DPNR \\
\cline { 2 - 4 } & Wet density $\left(\mathrm{g} / \mathrm{cm}^{3}\right)$ & Wet density $\left(\mathrm{g} / \mathrm{cm}^{3}\right)$ & Wet density $\left(\mathrm{g} / \mathrm{cm}^{3}\right)$ \\
\hline HD & 0.16 & 0.16 & 0.16 \\
MD & 0.12 & 0.12 & 0.12 \\
LD & 0.09 & 0.10 & 0.09 \\
\hline
\end{tabular}

Therefore, in this work, an additional dosage of P.O. was added into the DPNR latex to improve its foamability. Thus, to produce MD and LD of DPNR latex foam, additional $0.25 \mathrm{phr}$ and 0.5 phr of P.O. was added respectively. Similar to DPNR latex, ENR latex was unable to reach the targeted volume expansion within the targeted time. Therefore, additional $0.25 \mathrm{phr}, 0.5 \mathrm{phr}$ and $0.75 \mathrm{phr}$ of P.O. were added into the latex to produce HD, MD and LD of ENR latex foam respectively. For that reason, it can be concluded that the addition of extra P.O. as a foaming agent helped to improve the foamability of DPNR and ENR latex. Nevertheless, Table IV shows that the targeted wet density of ENR (LD) latex foam was found slightly higher than the targeted wet density. The reason behind this is still unclear and needs further investigation. After the latex foam achieved the desired degree of volume expansion, the speed of the foam mixer was reduced to refine the foam-cell structure. Then, $\mathrm{ZnO}$ and DPG were added. The latex foam was allowed to be continuously stirred for one minute to ensure $\mathrm{ZnO}$ and DPG are well dispersed in the latex foam. Then, $\mathrm{pH}$ value of the latex foam was recorded.

Table $\mathrm{V}$ shows that the $\mathrm{pH}$ value of the latex foam was reduced after the foaming process. The reduced $\mathrm{pH}$ value of the latex foam could be due to a chemical reaction between the $\mathrm{ZnO}$ + DPG and the latex and also due to the frothing process.

Table V

Effect of Compounding and Density Levels on pH Value of Latex Foam

\begin{tabular}{lccc}
\hline Stage of latex & $\begin{array}{c}\text { LATZ } \\
(\mathrm{pH})\end{array}$ & $\begin{array}{c}\text { ENR } \\
(\mathrm{pH})\end{array}$ & $\begin{array}{c}\text { DPNR } \\
(\mathrm{pH})\end{array}$ \\
\hline Compounded latex & 9.46 & 9.41 & 9.35 \\
Latex foam $+\mathrm{DPG}+\mathrm{ZnO}$ & $9.37^{\mathrm{a}} / 9.20^{\mathrm{b}} / 8.75^{\mathrm{c}}$ & $9.38^{\mathrm{a}} / 9.30^{\mathrm{b}} / 8.99^{\mathrm{c}}$ & $9.28^{\mathrm{a}} / 9.15^{\mathrm{b}} / 8.99^{\mathrm{c}}$ \\
\hline${ }^{\mathrm{a}}=\mathrm{HD} ;{ }^{\mathrm{b}}=\mathrm{MD} ;^{\mathrm{c}}=\mathrm{LD}$ & & &
\end{tabular}

According to Madge ${ }^{52}$, during the foaming process, a certain amount of ammonia has been lost 


\section{SPECIALTY NATURAL RUBBER LATEX FOAM: FOAMABILITY STUDY AND FABRICATION PROCESS}

to the atmosphere, thus changes the acidity of the latex foam. Therefore, this study agreed with the report made by Madge.$^{52}$ Further to that, this study observed that the lower the density of the latex foam the further the $\mathrm{pH}$ value was decreased. A similar trend was observed on each type of latexes used in this study.

The latex foam fabrication process was continued by the addition of SSF as the gelling agent. In this work, the effects of SSF on $\mathrm{pH}$ value and gelling time of latex foam produced at different density levels were investigated. Figure VII, Figure VIII and Figure IX show the results for LATZ, DPNR and ENR latex foam respectively. For LATZ, a gradual drop of $\mathrm{pH}$ value was observed after the addition of SSF. This study also observed that a higher level of SSF leads to bigger drop in $\mathrm{pH}$ value. However, this study observed that the addition of $0.4 \mathrm{phr}$ of SSF into LATZ (HD) latex foam, unable to gel the latex foam even after the latex foam was left to gel for 10 minutes.

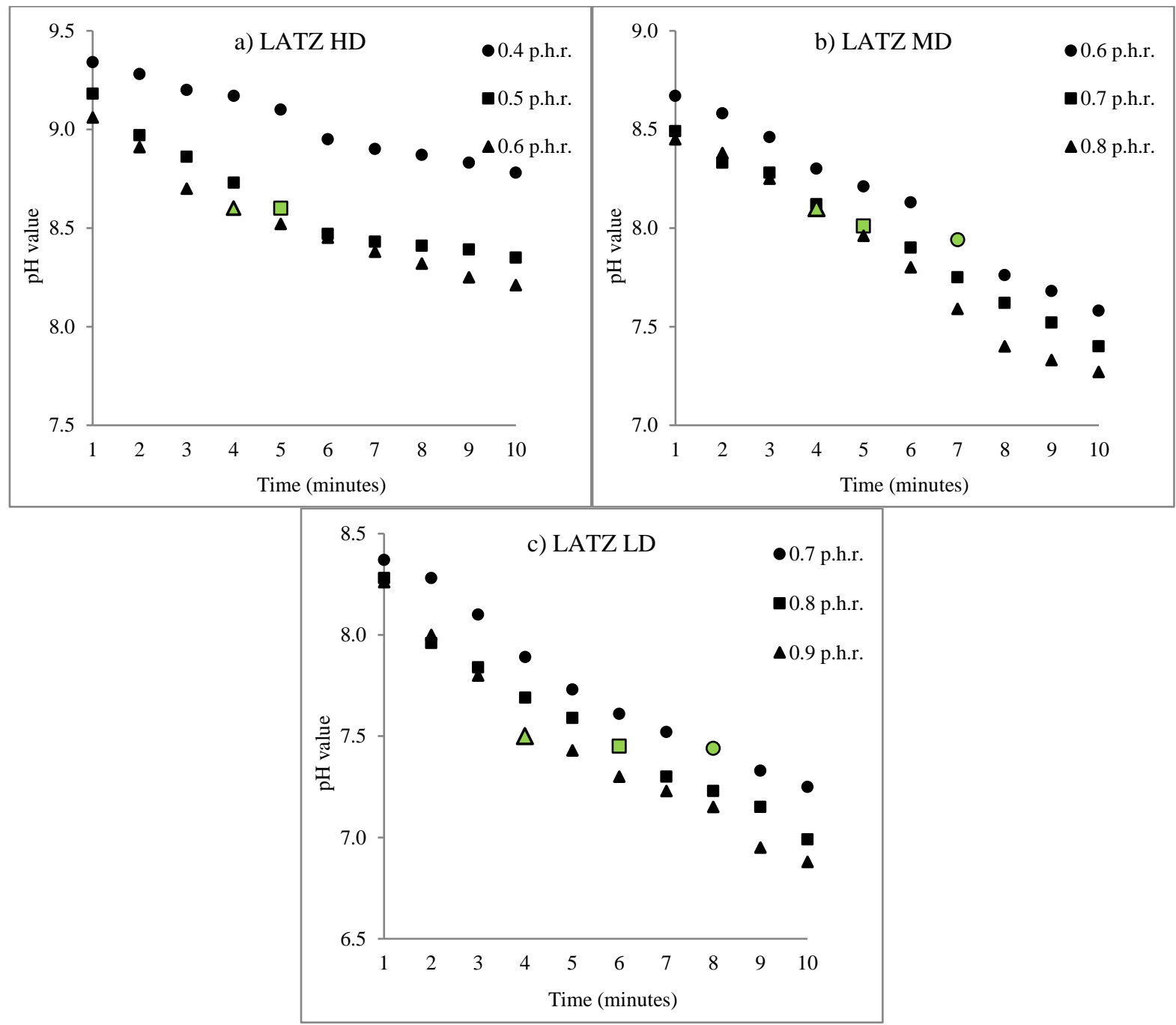

FIG VII. Effect of SSF levels on gelling time of LATZ latex foam

Green color indicates gelling time

Consequently, the latex foam tended to collapse. This indicates that $0.4 \mathrm{phr}$ of SSF used is too low. Therefore, the level of SSF was increased. This study found that, the addition of $0.5 \mathrm{phr}$ and $0.6 \mathrm{phr}$ of SSF was able to gel the latex foam within five and four minutes respectively. Both samples were observed to gel at $\mathrm{pH} 8.6$, almost similar to gelling $\mathrm{pH}$ value of 8.5 recorded by the previous study. ${ }^{27}$ Comparison between $0.5 \mathrm{phr}$ and $0.6 \mathrm{phr}$, gelling time $0.6 \mathrm{phr}$ is slightly faster than $0.5 \mathrm{phr}$. According to a previous study, ${ }^{52}$ in a well-balanced latex foam 


\section{RUBBER CHEMISTRY AND TECHNOLOGY}

formulation, latex foam required about five to seven minutes to set or completely gel. This is regarded as the time for transferring the latex foam from the bowl into the mold. Therefore, this study suggested that the best dosage of SSF for LATZ (HD) latex foam is $0.5 \mathrm{phr}$. Nevertheless, Figure VII revealed that different density levels require a different dosage of SSF whereas, LATZ latex foam MD and LD requires $0.7 \mathrm{phr}$ and $0.8 \mathrm{phr}$ of SSF respectively. Accordingly, the gelling time for MD and LD of LATZ latex foam was recorded at five and six minutes respectively. On the other hand, the gelling $\mathrm{pH}$ was recorded for MD and LD of LATZ latex foam was recorded at $\mathrm{pH} 8.0$ and $\mathrm{pH}$ 7.5. Generally, it can be observed that gelling time and gelling $\mathrm{pH}$ are influenced by the levels of SSF added. The level of SSF required depends on the density levels of the latex foam.

Similar to the LATZ latex foam, Figure VIII shows gradual drops of $\mathrm{pH}$ by time in each density level of DPNR latex foam after SSF was added. Nevertheless, results showed in Figure VIII indicated that DPNR latex requires higher levels of SSF to reach gel state compared to LATZ latex foam.

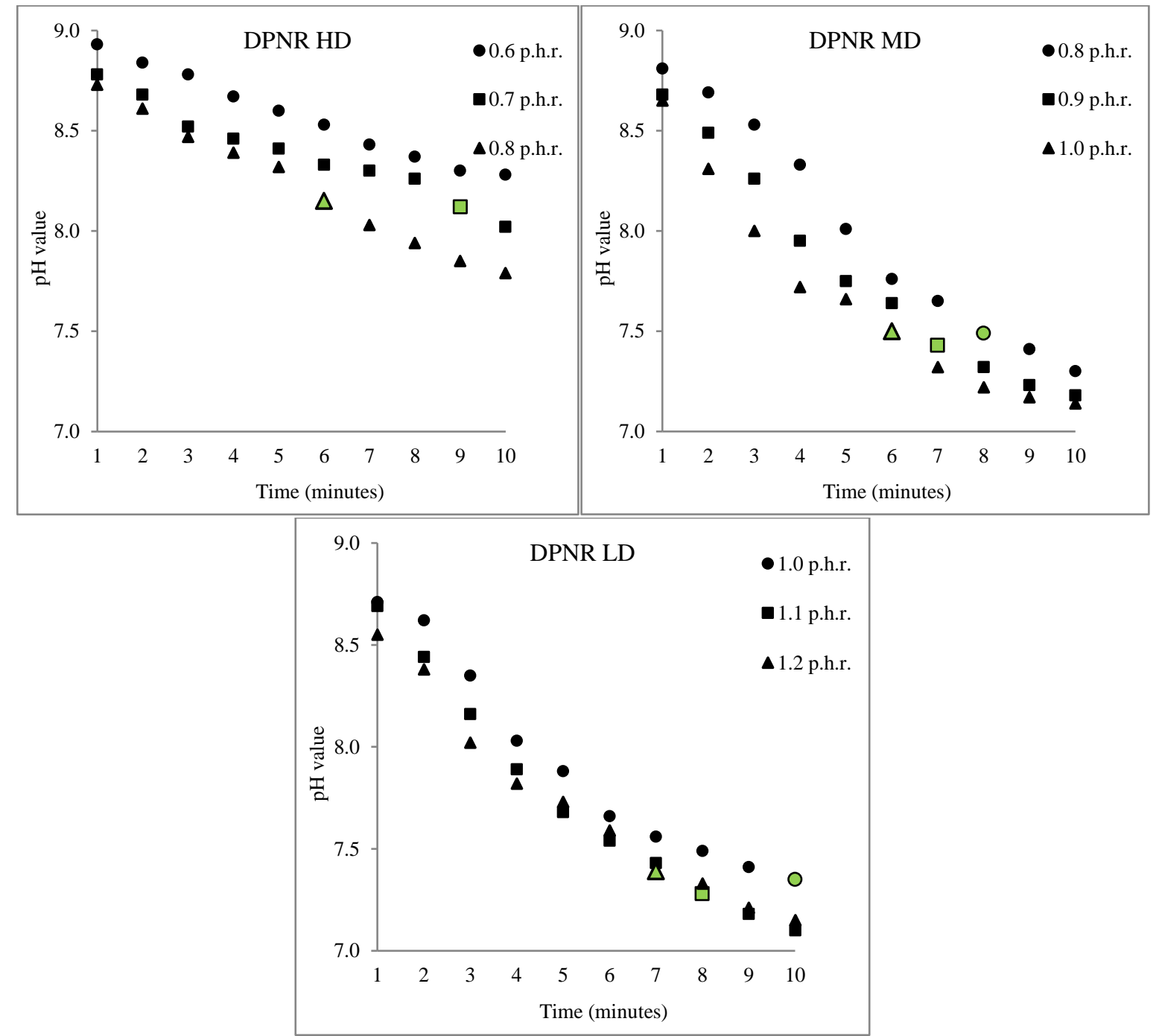

FIG VIII. Effect of SSF levels on gelling time of DPNR latex foam Green color indicates gelling time

For example, $0.5 \mathrm{phr}$ SSF was required to gel LATZ (HD) latex foam, but for DPNR (HD) latex foam, $0.8 \mathrm{phr}$ of SSF was required. This could be due to the presence of non-ionic surfactants in the DPNR latex system reacting with the chemical gelling agents thus preventing and delaying the gelling process. ${ }^{53}$ In addition, gelling $\mathrm{pH}$ of DPNR (HD) latex was observed 


\section{SPECIALTY NATURAL RUBBER LATEX FOAM: FOAMABILITY STUDY AND FABRICATION PROCESS}

lower than LATZ (HD) latex foam. A similar trend was observed on each density level of DPNR latex foam. Figure VIII shows that HD, MD and LD of DPNR latex foam were gel at $\mathrm{pH} 8.15, \mathrm{pH} 7.50$ and $\mathrm{pH} 7.40$, at gelling time of six, six and seven minutes using SSF levels of $0.8 \mathrm{phr}, 1.0 \mathrm{phr}$ and $1.2 \mathrm{phr}$ respectively.

On the other hand, ENR latex shows a longer gelling time than LATZ and DPNR latex foam. HD MD and LD of ENR latex foam were observed to gel at the gelling time of seven minutes, at $\mathrm{pH} 8.29, \mathrm{pH} 7.70$ and $\mathrm{pH} 7.50$, using SSF levels of $0.9 \mathrm{phr}, 1.10 \mathrm{phr}$ and $1.20 \mathrm{phr}$ respectively. This could be due to different chemicals composition in the ENR latex system as a result of the epoxidation process. Further to that, it should be noted that NR latex is stabilized by protein molecules, fatty acid soaps, surfactants (carboxylic anions) adsorbed on the surface of rubber particles. ${ }^{16}$ This negative charge produces repulsive forces and ensures the absence of aggregation. Reduction in $\mathrm{pH}$ by the addition of acids gelling agent reduces ionization of adsorbed anions and decreases the repulsive forces due to which gelation takes place ${ }^{41,52}$. Therefore, the slower rate of gelation of ENR latex foam in comparison to LATZ foam might be due to the presence of additional stabilizers or surfactants (i.e., ammonium laurate, potassium oleate).

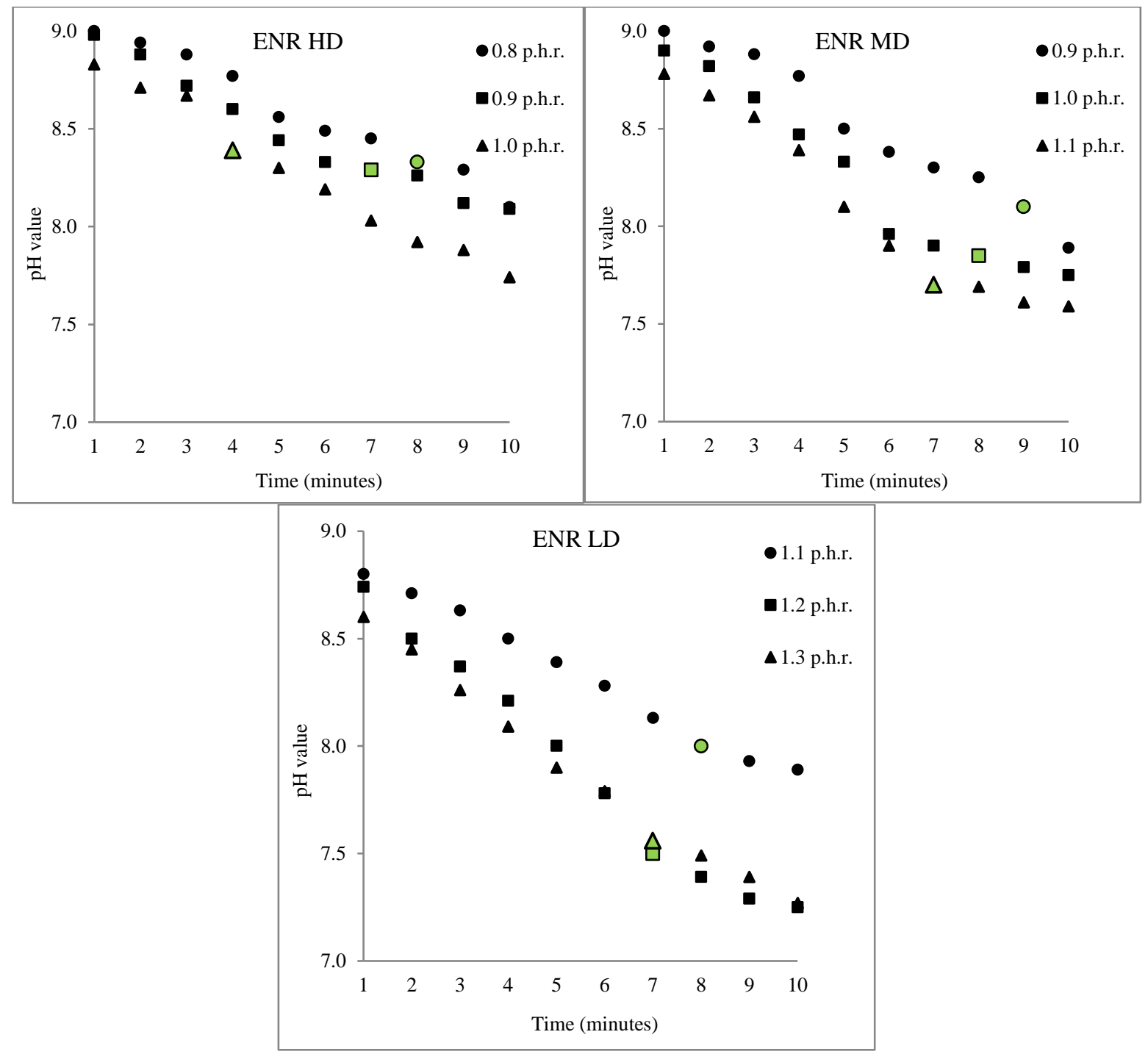

FIG IX. Effect of SSF levels on gelling time of ENR latex foam Green color indicates gelling time 


\section{RUBBER CHEMISTRY AND TECHNOLOGY}

\section{APPEARANCE}

Figure X shows the appearance of LATZ, DPNR and ENR latex foam produced in this study. The color of the dried latex foam appeared slightly different, whereas LATZ and DPNR latex foam visualized as off-white color, but ENR latex foam was visualized as creamy-yellow color. The creamy-yellow color of ENR latex foam could be due to epoxidation reactions as well as a heating process that was conducted at elevated temperatures for 24 hours. It should be noted that all latexes were able to foam at three different density levels and labelled as HD, MD and LD foams. However, after the vulcanization process, only LATZ and DPNR latex foam were successfully fabricated at three density levels. For ENR latex, ENR (LD) latex foam was observed to flop down to the centre of the latex foam sample like a crater after the vulcanization process. The reason behind this is not clear but possibly due to the poor wet gel strength of the material, as a result of the high level of stabilizer presence in the latex system. During the vulcanization process, the mold is closed with a lid. The lid has been manufactured with small hole to allow vaporize materials including water and ammonia to evaporate from mold leaving a solid latex foam material. However, during the evaporation process, the wet latex foam suffered from pressure differences in between the lid and top surface of the latex foam. At this stage, the foam-cell structure of the latex foam has not solidified, therefore, the pressure tended to push the latex foam to flop down. LD latex foam is a low-density latex foam, thus it is expected to have low wet strength compared to HD and MD latex foam. Therefore, this study assumes that, the weak wet gel strength of ENR (LD) latex foam is unable to oppose the pressure, thus lead the latex foam to flop down creating a crater during the vulcanization process.
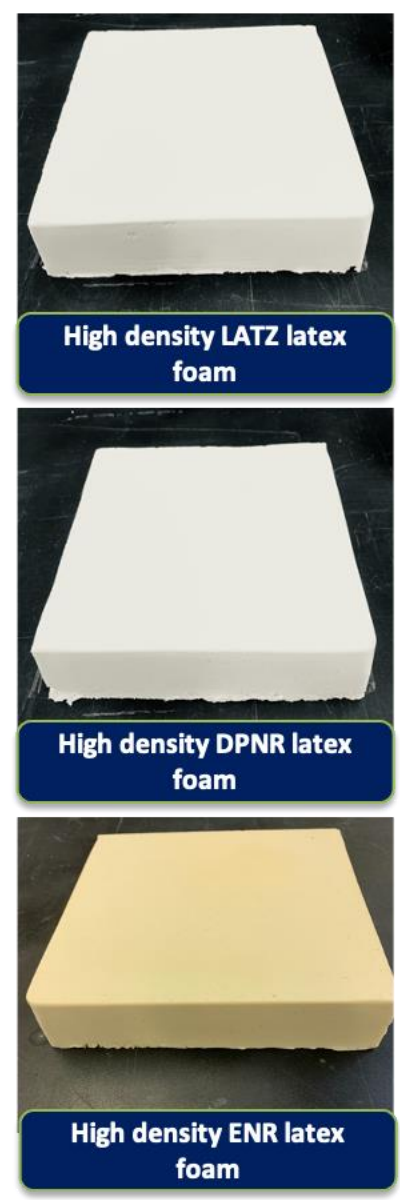
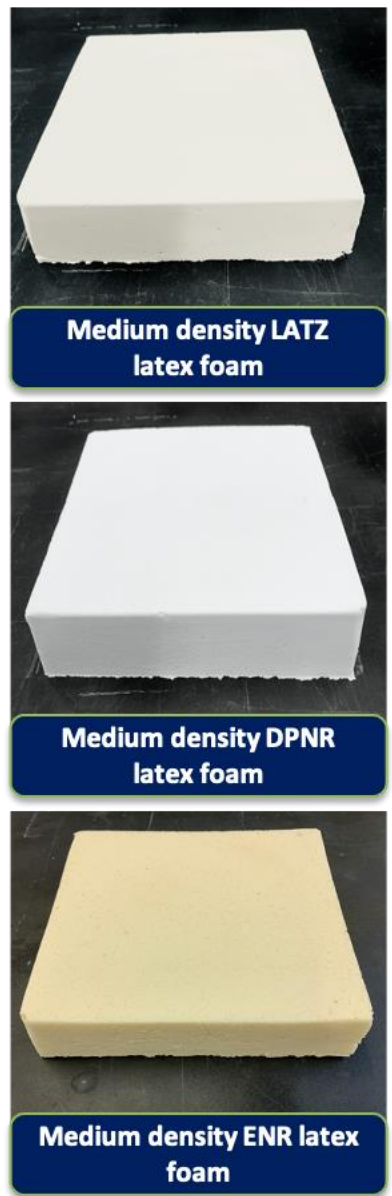
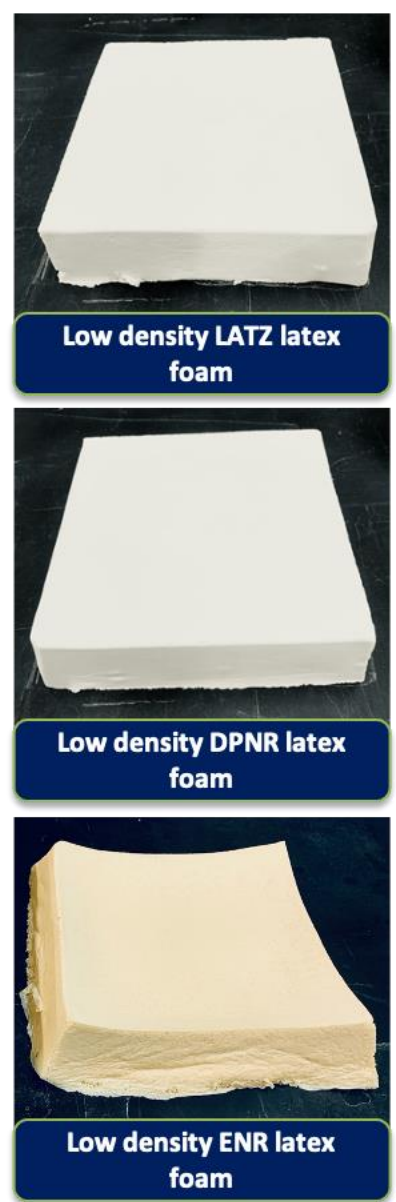

FIG X. Appearance of LATZ, DPNR and ENR latex foam 


\section{SPECIALTY NATURAL RUBBER LATEX FOAM: FOAMABILITY STUDY AND FABRICATION PROCESS}

\section{MORPHOLOGICAL STUDY}

Figure XI shows morphological structures of LATZ, DPNR and ENR latex foam prepared in this study. It can be observed that all latex foams exhibit interconnected microporous structure. It should be noted that, the Dunlop method is a mechanical foaming process that regulates pore formation poorly, leading to a non-homogeneous foam distribution. ${ }^{54}$ Observation on the pore size showed that, the pore size of HD latex foam is smaller compared MD and LD latex foam in each type of latex foams. This is expected because, the lower the density the higher the volume expansion. Consequently, the higher the volume expansion the bigger the growth of foam-cell size. Figure XI also visualized the morphological structure of LD ENR latex foam. Apparently, the foam-cell collapsed and coalesced to each other.
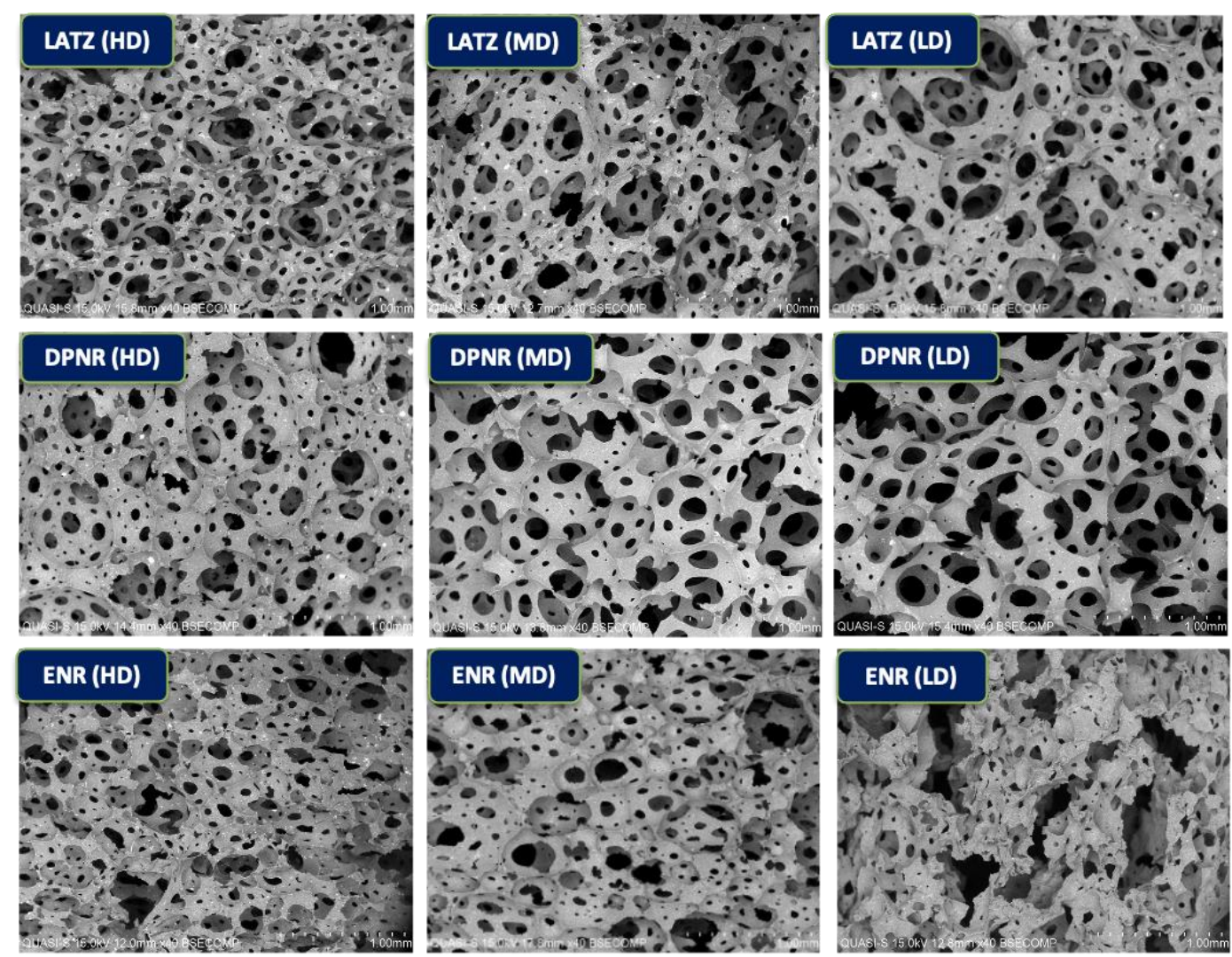

Scale

$1.00 \mathrm{~mm}$ $\mathrm{X} 40,15 \mathrm{kV}$

FIG XI. Micrographs of LATZ, DPNR and ENR latex foam

To further investigate the effect of density on pores size and porosity of the latex foams, ImageJ software was used. Figure XII indicated that, decreasing the density of the latex foam would increase the mean pore size of the latex foam. The smallest mean pore size was observed on ENR (HD) latex foam whilst the largest mean pore size was visible by DPNR (LD) latex foam. Porosity value corelates with the mean pore size whereas, porosity values increase when the mean pore size increases. DPNR (LD) latex foam exhibits the most porous material whereas the porosity of the material is more than 50\%. On the other hand, DPNR (HD) latex foam exhibits the most resistant material. For medium-density foam material, ENR (MD) latex foam exhibits the lowest porosity followed by LATZ (MD) and DPNR (MD) latex foam. 


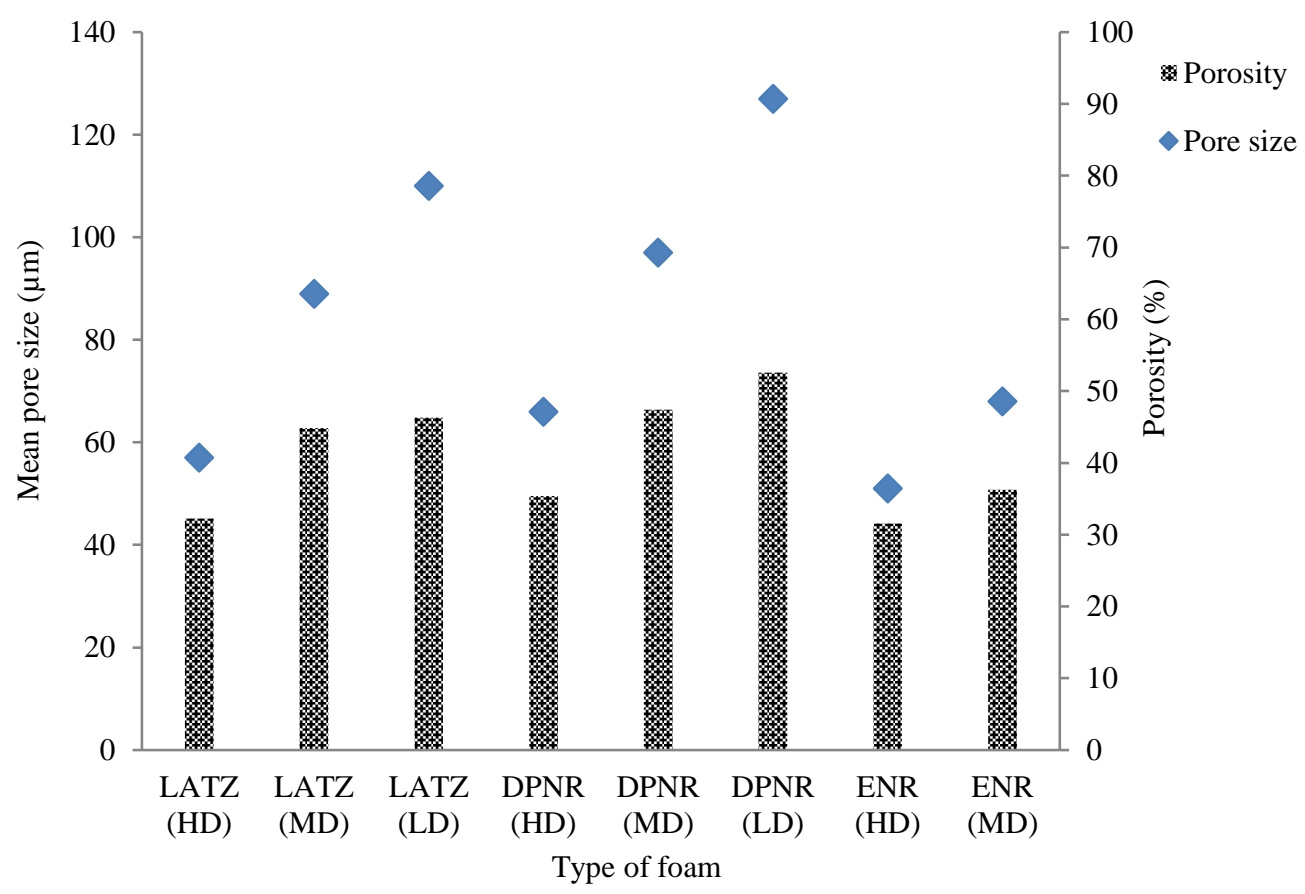

FIG XII. Mean pore size and porosity of latex foams

\section{EFFECT OF DENSITY ON VOLUME SHRINKAGE}

Table VI shows the dry density and volume shrinkage of latex foam fabricated in this study. It can be seen that, the dry density of all latex foams fabricated in this study was decreased to almost half of the wet density value.

Table VI

Effect of Density Levels on Volume Shrinkage

\begin{tabular}{lcccccc}
\hline & \multicolumn{2}{c}{ LATZ } & \multicolumn{2}{c}{ ENR } & \multicolumn{2}{c}{ DPNR } \\
\cline { 2 - 7 } Parameters & $\begin{array}{c}\text { Dry density } \\
\left(\mathrm{g} / \mathrm{cm}^{3}\right)\end{array}$ & $\begin{array}{c}\text { Volume } \\
\text { shrinkage } \\
(\%)\end{array}$ & $\begin{array}{c}\text { Dry density } \\
\left(\mathrm{g} / \mathrm{cm}^{3}\right)\end{array}$ & $\begin{array}{c}\text { Volume } \\
\text { shrinkage } \\
(\%)\end{array}$ & $\begin{array}{c}\text { Dry density } \\
\left(\mathrm{g} / \mathrm{cm}^{3}\right)\end{array}$ & $\begin{array}{c}\text { Volume } \\
\text { shrinkage }(\%)\end{array}$ \\
\hline HD & 0.10 & 12 & 0.11 & 13 & 0.10 & 12 \\
MD & 0.08 & 11 & 0.09 & 12.5 & 0.08 & 11 \\
LD & 0.06 & 10 & N/A & N/A & 0.06 & 11 \\
\hline
\end{tabular}

This study also found that, higher density latex foam exhibits higher volume shrinkage. No significant difference of volume shrinkage between LATZ and DPNR latex foam was observed. However, the volume shrinkage of ENR latex foam is higher than LATZ and DPNR latex foam. The reason behind this is not clear, but it is possibly due to chemical epoxidation reactions on the molecular structure of rubber which lead to changes in physical properties of the rubber material including volume shrinkage. Additionally, the higher volume shrinkage of ENR latex foam also might be due to higher SSF added during gelling process. ${ }^{41,52}$

\section{HYSTERESIS STUDY}

Figure XIII shows the stress-strain curve of DPNR and ENR latex foam obtained from the compression test. In this work, the $3^{\text {rd }}$ cycle of compression force-displacement curve was chosen because it has been suggested as the stable curve for the hysteresis study by the previous study $^{44}$. It should be noted that, as far as the authors' concern, this is the first time the stressstrain curve of DPNR and ENR latex foam has been presented, as no literature can be found. The results indicated that, at the first 0.2 strain, DPNR latex foam exhibits higher uploading 


\section{SPECIALTY NATURAL RUBBER LATEX FOAM: FOAMABILITY STUDY AND FABRICATION PROCESS}

stress value compared to ENR latex foam. However, beyond that strain value, ENR latex foam exhibits higher uploading stress value. This could be the formation of epoxy group in the rubber chains that increased the stiffness of ENR latex foam especially at high percentage of deformation.

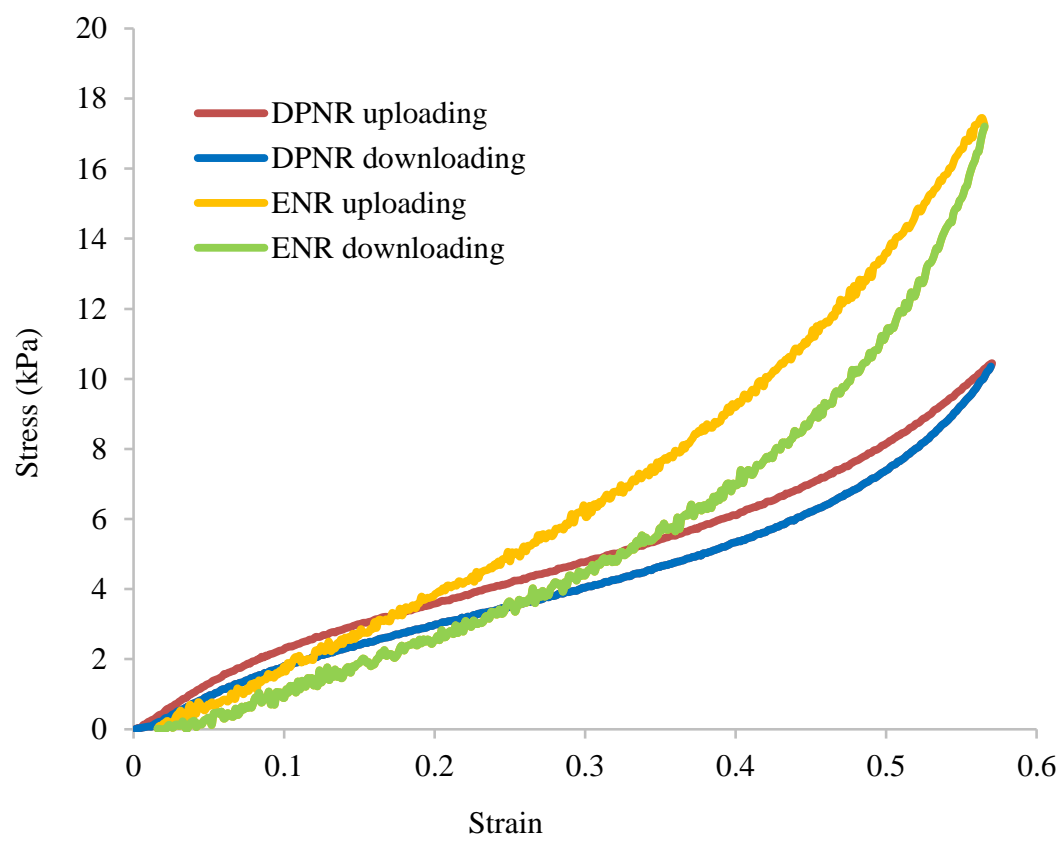

FIG. XIII. Hysteresis loop of medium-density DPNR and ENR latex foams

Figure XIII also demonstrates the hysteresis loop (between loading and unloading curve) of the DPNR and ENR latex foams. The hysteresis is defined as the energy loss (dissipation energy) per cycle of deformation. ${ }^{55}$ It is well understood that, the area under the loading curve is the total mechanical energy input whilst, the area under the unloading curve is the return of stored energy and the area between the two curves is the dissipated energy that converted to heat. ${ }^{51}$ The importance of the hysteresis measurement is that it gives a strong indicator about the material capacity to absorb energy and/or relief pressure. ${ }^{56,57}$ Apparently, ENR latex foam exhibits larger hysteresis loop compared to DPNR latex foam. Previous study ${ }^{44}$ cited, hysteresis loss ratio can be calculated from a stable hysteresis loop, and the hysteresis loss ratio equation is given as follows,

$$
\text { Hysteresis loss ratio }=\frac{H}{E}
$$

where $H$ is the amount of hysteresis (dissipated energy, given by the difference of the area under the uploading and the unloading curve) and $E$ is the supplied energy during uploading (given by the area under the unloading curve).

Figure XIV indicates that hysteresis loss ratio of ENR latex foam is higher than DPNR latex foam. It is well-known that, the higher hysteresis loss ratio the higher damping property of the material. Since the compounding formulation and density level (medium-density) of both DPNR and ENR latex foam are the same, the higher hysteresis loss ratio of ENR latex foam might be due to its high-damping property originated from the epoxy group in the rubber chains. 


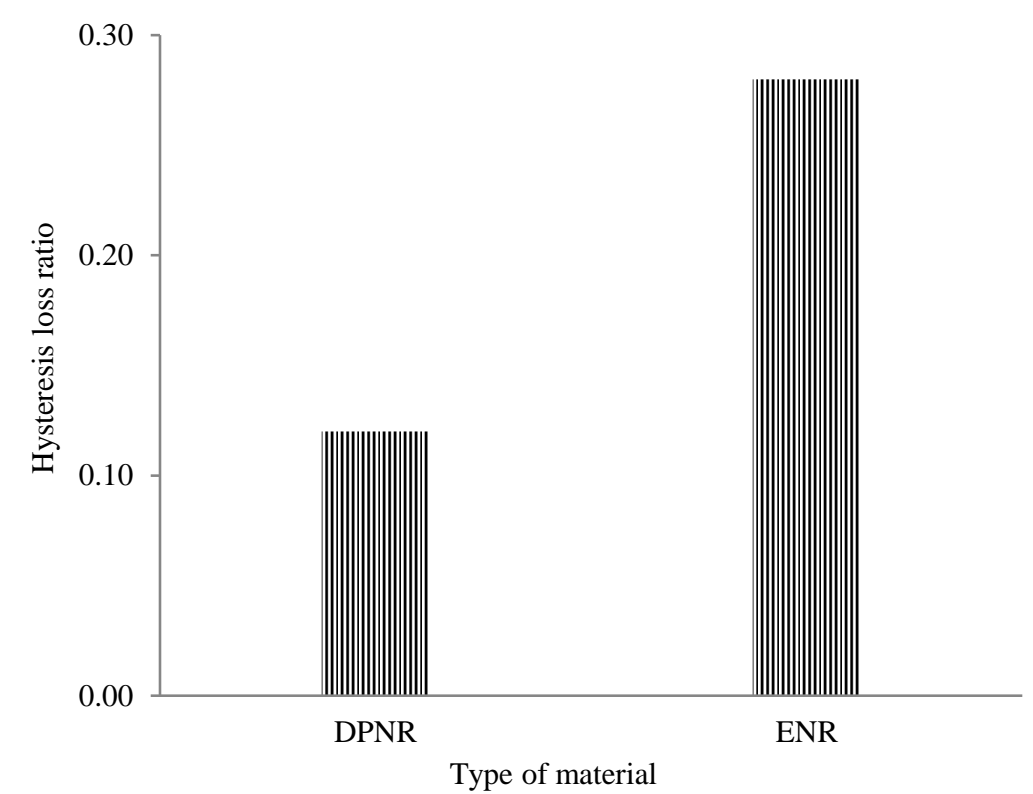

FIG. XIV. Hysteresis loss ratio of DPNR and ENR latex foams

\section{CONCLUSION}

This study proved that, SpNR latex concentrate can be used to produced latex foam. Foamability of SpNR latex is lower compared to normal latex (LATZ), but shows a longer stability time after foamed. Foam collapse and foam coagulate are two main challenges in the fabrication of SpNR latex foam which can be solved by altering the foaming levels and gelling ingredients. Each type of latex requires different quantities of gelling ingredients. Gelling time and gelling $\mathrm{pH}$ are influenced by latex foam density and gelling agent added. This work provides ideal compounding, foaming and gelling formulations for the fabrication of SpNR latex foam via Dunlop batch foaming process. DPNR latex can be used to produce low-density latex foam similar to LATZ latex foam. On the other hand, ENR latex can only be used to produce medium and high-density latex foam. The morphological study indicated all latex foams are open-cell structures, with lower density foam exhibits higher porosity and mean pore size. Comparison of hysteresis behavior between DPNR and ENR latex foam indicated that, ENR latex foam exhibits a higher hysteresis loss ratio compared to DPNR latex foam.

\section{ACKNOWLEDGEMENT}

This study is part of a $\mathrm{PhD}$ study. The authors are grateful for the financial support and facilities provided by the Malaysian Rubber Board and the University of Nottingham. The authors also would like to thank Ahmad Syaheer Abu Aswad and Hishamudin Samat for their technical assistance during the duration of the study. The authors declare that there is no conflict of interest regarding the publication of this paper.

\section{REFERENCES}

${ }^{1}$ L. Tarachiwin, J.T. Sakdapipanich, and Y. Tanaka, Rubber Chem. Technol. 78, 694 (2005).

${ }^{2}$ C. Okolieocha, D. Raps, K. Subramaniam, and V. Altstädt, Eur. Polym. J. 73, 500 (2015).

${ }^{3}$ K.C. Frisch, J. Macromol. Sci. Part A - Chem. 15, 1089 (1981). 


\section{SPECIALTY NATURAL RUBBER LATEX FOAM: FOAMABILITY STUDY AND FABRICATION PROCESS}

${ }^{4}$ M.P. Motloung, V. Ojijo, J. Bandyopadhyay, and S.S. Ray, Polymers (Basel). 11, (2019).

${ }^{5}$ P.A. Weller, Rubber Chem. Technol. 46, 843 (1973).

${ }^{6}$ Y. Liang, Energy Absorption Properties of Cellular Materials with Maximum Bulk Modulus, MSc. Thesis, RMIT University, Australia, 2017.

${ }^{7}$ L. Chen, D. Rende, L.S. Schadler, and R. Ozisik, J. Mater. Chem. A 1, 3837 (2013).

${ }^{8}$ V.G. Nuno, F. Artur, and B.T. Ana, Materials (Basel). 11, 1 (2018).

${ }^{9}$ S. Poulikidou, Integration of Design for Environment in the Vehicle Manufacturing Industry in Sweden: Focus on Practices and Tools, PhD Thesis, KTH, Royal Institute of Technology, Sweden, 2013.

${ }^{10}$ T. Eduardo, Polymer Composite Materials Based on Bamboo Fibres, PhD Thesis, KU Leuven, Belgium, 2014.

${ }^{11}$ C.R. Hall, B.L. Campbell, B.K. Behe, C. Yue, R.G. Lopez, and J.H. Dennis, HortScience 45, 583 (2010).

${ }^{12}$ V. Albino, A. Balice, and R.M. Dangelico, Bus. Strateg. Environ. 18, 83 (2009).

${ }^{13}$ L. Simão and A. Lisboa, Procedia Manuf. 12, 183 (2017).

14 A. Gandini, Macromolecules 41, 9491 (2008).

${ }^{15}$ M. Avella, A. Buzarovska, M.E. Errico, G. Gentile, and A. Grozdanov, Materials (Basel).

2, 911 (2009).

16 D.C. Blackley, Polymer Latices and Technology. Volume 2: Types of Latices, 2nd ed. (Chapman \& Hall, London, U.K., 1997).

${ }^{17}$ M.Y. Amir Hashim, R. Roslim, and M.W. Rosni, J. Rubber Res. 15, 243 (2012).

${ }^{18}$ R. Roslim and M.Y. Amir Hashim, J. Rubber Res. 13, 125 (2010).

${ }^{19}$ M.R. Fatimah Rubaizah, M.Y. Amir Hashim, Y. Nurul Hayati, A. Mohamad Asri, R. Roslim, and A.B. Rohani, Rubber World 259, 32 (2018).

${ }^{20}$ H. Rosniza, Structural Study of Epoxidized Natural Rubber (Enr-50) and Its Derivatives Synthesized via Epoxide Ring-Opening Reactions Using NMR Techniques, PhD Thesis, Universiti Sains Malaysia, 2015.

${ }^{21}$ S. Siti Salina, A.A. Azira, C.A. Ahmad Kifli, A.R. Rohaidah, and N.I. Nik Intan, J. Polym. Sci. Technol. 2, 36 (2017).

${ }^{22}$ W. Ariyawiriyanan, J. Nuinu, K. Sae-Heng, and S. Kawahara, Energy Procedia 34, 728 (2013).

23 J. Yunyongwattanakorn, Y. Tanaka, S. Kawahara, W. Klinklai, and J. Sakdapipanich, Rubber Chem. Technol. 76, 1228 (2003).

${ }^{24}$ K. Shamsul, A.F. Ramly, N. Mohd Shukri, A.G. Bakri, and Q. Fourrier, in Int. Rubber Conf. (Kuala Lumpur, Malaysia, 3-5 September 2018).

${ }^{25}$ J.M. Pamela, B. Paul, C. Adrew, and C. Stuart, Rubber Chem. Technol. 88, 390 (2015).

${ }^{26}$ Y. Tanaka and L. Tarachiwin, Rubber Chem. Technol. 82, 283 (2009).

${ }^{27}$ H.M. Lim and M.Y. Amir-Hashim, J. Rubber Res. 14, 41 (2011).

${ }^{28}$ V. Devaraj, Fouling Studies on Natural Rubber Skim Latex Concentration Using Integrated Ultrafiltration Membrane System, PhD Thesis, Universiti Teknologi Malaysia, 2015.

${ }^{29}$ V. Devaraj, M.N. Zairossani, and S. Pretibaa, J. Appl. Mem. Sci. Technol. 4, 13 (2006).

${ }^{30}$ I. Aimi Izyana, S. Pretibaa, A. Azhar, and M. Ahmad Khairul, Bul. Sains Dan Teknol. 13, 18 (2014).

${ }^{31}$ X. Zhu, B.J. Kim, Q.W. Wang, and Q. Wu, BioResources 9, 1764 (2014).

${ }^{32}$ A. Abbad, K. Jaboviste, M. Ouisse, and N. Dauchez, J. Cell. Plast. 54, 651 (2018).

${ }^{33}$ F. Setaki, M. Tenpierik, A. Van Timmeren, and M. Turrin, in 44th Int. Congr. Expo. Noise Control Eng. (California, USA, 9-12 August 2015).

${ }^{34}$ S.E. Roper, (2009).

${ }^{35}$ S. Palk, M. De Geest, and K. Vansant, Sound Vib. 47, 10 (2013).

${ }^{36}$ R. Roslim, K. Shamsul, M.R. Fatimah Rubaizah, K.L. Mok, and A.H. Aziana, Malaysian 


\section{RUBBER CHEMISTRY AND TECHNOLOGY}

Rubber Technol. Dev. 18, 38 (2018).

${ }^{37}$ R. Roslim, K.L. Mok, M.R. Fatimah Rubaizah, K. Shamsul, K.S. Tan, and M.Y. Amir Hashim, in Int. Rubber Conf. (Kuala Lumpur, Malaysia, 3-5 September 2018).

${ }^{38}$ V. Devaraj, N. Zairosani M, S. Pretibaa, and I. Aimi Izyana, Malaysian Patent Application Number: PI 2012004868 (2012).

${ }^{39}$ M.R. Fatimah Rubaizah, V. Devaraj, A.R. Mohamad Akmal, M.N. Zairossani, D. Dazylah, and A.A. Azira, Malaysian Patent Application Number: PI2017700457 (2017).

40 R. Roslim, K. Shamsul, and M.R. Fatimah Rubaizah, Patent Application Number PI2020004246 (2020).

${ }^{41}$ The Malaysian Rubber Producers' Research Association, The Natural Rubber Formulary and Property (Inprint of Luton Limited, London, U.K., 1984).

${ }^{42}$ D.C. Blackley, Polymer Latices and Technology. Volume 3: Applications of Latices, 2nd ed. (Chapman \& Hall, London, U.K., 1997).

${ }^{43}$ R. Roslim, M.Y. Amir Hashim, and P.T. Augurio, J. Eng. Sci. 8, 15 (2012).

${ }^{44}$ A.B. Chai, S. Kamaruddin, K.Y. Tshai, I. Kong, B.J.H. Tay, and S.Y. Ch'ng, J. Eng. Appl. Sci. 11, 128 (2016).

${ }^{45}$ K.K. Sasidharan, R. Joseph, S. Palaty, K.S. Gopalakrishnan, G. Rajammal, and P.V. Pillai, J. Appl. Polym. Sci. 97, 1804 (2005).

${ }^{46}$ P.F. Lai, J. Nat. Rubber Res. 6, 257 (1991).

${ }^{47}$ S. Mathew and S. Varghese, Rubber Sci. 31, 249 (2018).

${ }^{48}$ Arvind Mafatal Group, NR Latex \& Latex Products (Nocil Limited, Gujarat, India, 2010).

${ }^{49}$ Q. Sun, L. Tan, and G. Wang, Int. J. Mod. Phys. B 22, 2333 (2008).

${ }^{50}$ S. Manroshan and M.R. Fatimah Rubaizah, J. Rubber Res. 22, 153 (2019).

${ }^{51}$ M. Safouane, A. Saint-Jalmes, V. Bergeron, and D. Langevin, Eur. Phys. J. E 19, 195 (2006).

${ }^{52}$ E.W. Madge, Latex Foam Rubber (MacLaren and Sons Ltd., London, U.K., 1962).

${ }^{53}$ D.J. McKeand, Ind. Eng. Chem. 43, 415 (1951).

${ }^{54}$ S. Phomrak, A. Nimpaiboon, B.M.Z. Newby, and M. Phisalaphong, Polymers (Basel). 12, 1 (2020).

${ }^{55}$ N.J. Mills, Cell. Polym. 25, 293 (2006).

${ }^{56}$ M.L. Ju, H. Jmal, R. Dupuis, and E. Aubry, Polym. Eng. Sci. 55, 1795 (2015).

${ }^{57}$ F. Fiorentini, M. Cakmak, and S.K. Mowdood, Rubber Chem. Technol. 79, 55 (2006). 